Atmos. Chem. Phys., 10, 8391-8412, 2010

www.atmos-chem-phys.net/10/8391/2010/

doi:10.5194/acp-10-8391-2010

(C) Author(s) 2010. CC Attribution 3.0 License.

\title{
Fluxes and concentrations of volatile organic compounds from a South-East Asian tropical rainforest
}

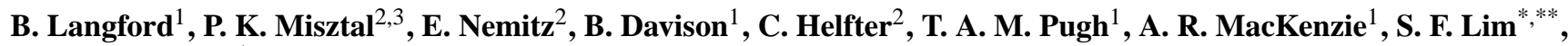 \\ and C. N. Hewitt ${ }^{1}$ \\ ${ }^{1}$ Lancaster Environment Centre, Lancaster University, LA1 4YQ, UK \\ ${ }^{2}$ Centre for Ecology \& Hydrology, Bush Estate, Penicuik, EH26 0QB, UK \\ ${ }^{3}$ School of Chemistry, Edinburgh University, Edinburgh, EH9 3JJ, UK \\ * formerly at: Malaysian Meteorological Department, Jalan Sultan, Petaling Jaya, Selangor Darul Ehsan, Malaysia \\ *** retired
}

Received: 20 April 2010 - Published in Atmos. Chem. Phys. Discuss.: 6 May 2010

Revised: 6 August 2010 - Accepted: 1 September 2010 - Published: 7 September 2010

\begin{abstract}
As part of the OP3 field study of rainforest atmospheric chemistry, above-canopy fluxes of isoprene, monoterpenes and oxygenated volatile organic compounds were made by virtual disjunct eddy covariance from a SouthEast Asian tropical rainforest in Malaysia. Approximately 500 hours of flux data were collected over 48 days in AprilMay and June-July 2008. Isoprene was the dominant nonmethane hydrocarbon emitted from the forest, accounting for $80 \%$ (as carbon) of the measured emission of reactive carbon fluxes. Total monoterpene emissions accounted for $18 \%$ of the measured reactive carbon flux. There was no evidence for nocturnal monoterpene emissions and during the day their flux rate was dependent on both light and temperature. The oxygenated compounds, including methanol, acetone and acetaldehyde, contributed less than $2 \%$ of the total measured reactive carbon flux. The sum of the VOC fluxes measured represents a $0.4 \%$ loss of daytime assimilated carbon by the canopy, but atmospheric chemistry box modelling suggests that most (90\%) of this reactive carbon is returned back to the canopy by wet and dry deposition following chemical transformation. The emission rates of isoprene and monoterpenes, normalised to $30^{\circ} \mathrm{C}$ and $1000 \mu \mathrm{mol} \mathrm{m}^{-2} \mathrm{~s}^{-1}$ PAR, were $1.6 \mathrm{mg} \mathrm{m}^{-2} \mathrm{~h}^{-1}$ and $0.46 \mathrm{mg} \mathrm{m}^{-2} \mathrm{~h}^{-1}$ respectively, which was 4 and 1.8 times lower respectively than the default value for tropical forests in the widely-used MEGAN
\end{abstract}

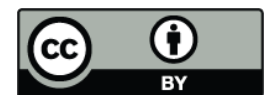

Correspondence to: $\mathrm{B}$. Langford (b.langford1@lancaster.ac.uk) model of biogenic VOC emissions. This highlights the need for more direct canopy-scale flux measurements of VOCs from the world's tropical forests.

\section{Introduction}

Trees assimilate carbon from the atmosphere through the process of photosynthesis, as a result of which, tropical forests are estimated to sequester up to $1.3 \mathrm{Pg}$ of carbon annually (Lewis et al., 2009). Some of this assimilated carbon is released back into the atmosphere in the form of reactive volatile organic compounds such as isoprene and monoterpenes (Laothawornkitkul et al., 2009). Emissions of biogenic volatile organic compounds (BVOC) therefore contribute to the global carbon cycle. They can influence both atmospheric composition and global climate in several key ways. First, due to their high reactivity with respect to the hydroxyl radical $(\mathrm{OH})$, BVOC emissions mediate the oxidative capacity of the Earth's atmosphere, possibly amplifying the persistence of important greenhouse gases such as methane and HCFCs (Granier et al., 2000; Lelieveld et al., 2002). Secondly, monoterpenes and sesquiterpenes are known to be precursors for biogenic secondary organic aerosol (BSOA) (e.g., Hallquist et al., 2009), which are radiatively active and hence important in the global climate system. There is evidence to suggest that isoprene may also contribute to BSOA formation (Claeys et al., 2004; Paulot et al., 2009). Chamber

Published by Copernicus Publications on behalf of the European Geosciences Union. 
studies have shown the aerosol yield from isoprene to be small or negligible (Kroll et al., 2005, 2006; Kleindienst et al., 2006; $\mathrm{Ng}$ et al., 2008), yet the globally high emission rates of isoprene (500-750 $\mathrm{Tg} \mathrm{yr}^{-1}$; Guenther et al., 2006) indicate that its contribution to organic aerosol may be significant (Zhang et al., 2007; Robinson et al., 2010), perhaps through the formation of water soluble compounds such as hydroxyhydroperoxides and epoxides (Paulot et al., 2009). However, Kiendler-Scharr et al. (2009) have demonstrated how isoprene emissions may actually suppress BSOA formation in a plant chamber study and thus its role remains unclear. Finally, in the presence of oxides of nitrogen, VOCs mediate in the formation of photochemical pollutants such as tropospheric ozone and peroxyacetyl nitrate (PAN) (e.g., Sillman, 1999; Hewitt et al., 2009). At high concentrations, ozone can be directly toxic with detrimental impacts on human health, crops and forests (Fowler, 2008).

Despite the important roles played by VOCs in mediating atmospheric composition and climate, relatively little is known about their emission rates from tropical forests. Current estimates suggest that these regions may account for up to half of all global BVOC emissions (Guenther et al., 2006), yet this estimate is based on a limited number of field studies. To date, the majority of these field observations have focused on tropical forests in Amazonia (Zimmerman et al., 1998; Helmig et al., 1998; Stefani et al., 2000; Rinne et al., 2002; Kuhn et al., 2007; Karl et al., 2007; Muller et al., 2008; Karl et al., 2009) and, to a lesser extent, regions of Africa (Klinger et al., 1998; Greenberg et al., 1999; Serca et al., 2001).

In current global biogenic VOC emission models such as the Model of Emissions of Gases and Aerosols from Nature (MEGAN G06) (Guenther et al., 2006), emissions of isoprene from the world's tropical forests are, in part, based on standardised emission rates calculated using measurements conducted in Amazonia. This assumes a degree of uniformity across all tropical forests, which has yet to be confirmed by independent observations and which would be surprising, considering the variety of tree species in rainforests (Pitman et al., 1999), and the very substantial interspecies differences in BVOC emission rates amongst those species that have been measured (Guenther, 1997). The influence of seasonality, which has been shown to be significant in Amazonia (Kuhn et al., 2002; Muller et al., 2008; Barkley et al., 2009), but other important tropical forest regions have little or no seasonality in their climate (e.g. Borneo), again requiring model emission algorithms to be more region-specific. As well as providing improved estimates of natural BVOC emissions, region-specific measurements also benchmark the BVOC chemical climatology from which land-use change is causing deviations (Misztal et al., 2010a), with potentially serious implications for regional air quality (Hewitt et al., 2009). There is, therefore, an obvious need for more landscape-scale flux measurements, especially in SE Asia where to date no direct micrometeorological flux observations have been made.
Here we present both direct canopy-scale concentration and flux measurements of a range of BVOCs (but not methane) above a tropical rainforest in SE Asia and compare the results to observations made in Amazonia and Africa (Sect. 3.2.1). Our findings are discussed in relation to the meteorology and then used to optimise the light and temperature algorithms of the MEGAN model for the tropical forests of SE Asia (Sect. 3.2.2). Finally, the measured VOC fluxes are related to co-located measurements of $\mathrm{CO}_{2}$ exchange and a canopy carbon budget is calculated.

\section{Methods}

\subsection{Site description and setup}

Measurements were made as part of the OP3 (Oxidant and Particle Photochemical Processes above a South-East Asian Rainforest) project (Hewitt et al., 2010a) at the Bukit Atur global atmosphere watch (GAW) station in the Danum Valley region of Sabah, Malaysia $\left(4^{\circ} 58^{\prime} 49.33^{\prime \prime} \mathrm{N}, 117^{\circ} 50^{\prime} 39.05^{\prime \prime} \mathrm{E}\right.$, $426 \mathrm{~m}$ above mean sea level). The aims and objectives of the OP3 project are summarised by Hewitt et al. (2010a), who also give a detailed site description and overview of the measurements located at the GAW station. The flux footprint of the tower encompassed areas of both primary and selectively logged forest, with regions of both clear-felled-forest and oil palm plantations found some distance beyond, well outside the flux footprint. The selectively logged forest in the flux footprint was logged in 1988 and has since been rehabilitated by enrichment planting. Measurements were carried out over two separate four week periods with phase 1 (OP3-I) taking place during the months of April and May 2008 and phase 2 (OP3-III) occurring between June and July 2008. OP3-II consisted of measurements at a nearby oil palm plantation (Misztal et al., 2010a).

For analysis of VOC concentrations and fluxes, a highsensitivity proton transfer reaction mass spectrometer (PTRMS) (Ionicon Analytik GmbH: Lindinger et al., 1998) equipped with three Varian turbo molecular pumps and heated Silcosteel inlet was used in conjunction with an ultrasonic anemometer (Windmaster Pro, Gill Instruments, UK). The anemometer and main gas sample line (PTFE, 1/2" OD, $0.36^{\prime \prime} \mathrm{ID}$ and approximately $90 \mathrm{~m}$ in length) were fixed to a $2 \mathrm{~m}$ boom mounted on the northeast edge of the tower at a height above ground level of $75 \mathrm{~m}$. As the GAW tower is a $100 \mathrm{~m}$ tall open pylon-type tower located on a hill, the effective measurement height was estimated to be between 100$150 \mathrm{~m}$ above the forest canopy below (Helfter et al., 2010). The PTR-MS was housed inside an air-conditioned laboratory located at the base of the tower and sub-sampled from an uncontrolled low pressure $\left(60 \mathrm{kPa}\right.$; flow rate $\left.601 \mathrm{~min}^{-1}\right)$ inlet line at a rate of $0.31 \mathrm{~min}^{-1}$ via a short length $(10 \mathrm{~cm})$ of PTFE tubing ( $\left.1 / 8^{\prime \prime} \mathrm{OD}, 0.03^{\prime \prime} \mathrm{ID}\right)$. All tubing in the air conditioned room was heated to $40^{\circ} \mathrm{C}$ to prevent condensation. Visual 
inspection and good agreement between $\mathrm{CO}_{2}$ and $\mathrm{H}_{2} \mathrm{O}$ fluxes measured with open and closed path sensors (sharing the same line) (Siong et al., 2010) confirmed that no condensation occurred in the main inlet. Data from each sensor were logged onto a single laptop computer in combination with meteorological observations using a program written in LabVIEW 8.5 (National Instruments, Austin, Texas, USA).

Throughout the measurement period the PTR-MS operating conditions were held constant to maintain an $E / N$ ratio of approximately $140 \mathrm{Td}$, which represented the best compromise between the optimal detection limit for VOCs and the minimisation of the impact of high relative humidity (Hayward et al., 2002; Hewitt et al., 2003; Tani et al., 2004). Drifttube pressure, temperature and voltage were typically maintained at $0.165 \mathrm{kPa}, 45^{\circ} \mathrm{C}$ and $500 \mathrm{~V}$ respectively, which gave a primary ion count in the range 6 to $8 \times 10^{6}$ ion counts per second (cps). The sensitivity $\left(S_{\text {norm }}\right.$ ) of the PTR-MS for each atomic mass unit (amu, $m / z)$ was calculated at regular intervals using a gas standard (Apel-Riemer Environmental Inc.), which contained methanol, acetonitrile, acetaldehyde, acetone and isoprene at a nominal concentration of $1.0 \mathrm{ppmv}$ each as well as limonene at $0.18 \mathrm{ppmv}$. Volume mixing ratios were calculated adopting the approach of Taipale et al. (2008), where the operating conditions of the PTR-MS are first standardised by normalizing the primary ion count to $1 \times 10^{6} \mathrm{cps}$ and accounting for the first water cluster:

$\mathrm{VMR}=\left(\frac{I\left(\mathrm{RH}^{+}\right)_{\text {norm }}}{S_{\mathrm{norm}}}\right)$

In this equation $I\left(\mathrm{RH}^{+}\right)_{\text {norm }}$ is the normalised count rate (ncps) of an individual $\mathrm{m} / \mathrm{z}$ which is calculated using Eq. (2):

$I\left(\mathrm{RH}^{+}\right)_{\text {norm }}=10^{6}\left(\frac{\mathrm{RH}_{i}}{M 21+M 37}-\frac{\mathrm{RH}_{\text {zero }}}{M 21_{\text {zero }}+M 37_{\text {zero }}}\right)$

Here $\mathrm{RH}_{i}$ represents the ion count signal at mass $\mathrm{M}_{i}$ (cps), $\mathrm{RH}_{\text {zero }}$ is the signal of the mass measured from the zero air source, $M 21$ and $M 37$ are the counts of the primary $\left(\mathrm{H}_{3}^{18} \mathrm{O}^{+}\right)$ and reagent cluster ions $\mathrm{H}_{3}^{16} \mathrm{O}^{+} \mathrm{H}_{2}^{16} \mathrm{O}^{+}$, respectively, while $\mathrm{M} 21_{\text {zero }}$ and $\mathrm{M} 37_{\text {zero }}$ are the primary and reagent cluster ions when measuring from the zero air source.

Monoterpenes fragment in the drift tube to $\mathrm{m} / \mathrm{z} 81$ and 137 in a humidity dependent process, hence their sensitivities were calculated as the sum of the two masses. For those compounds not contained in the gas mixture, empirical sensitivities were calculated based on the instrumentspecific transmission characteristics. The transmission curve was calculated empirically in two stages, using two separate approaches. For the compounds in the lower $\mathrm{m} / \mathrm{z}$ range, transmission coefficients were calculated using the approach of Taipale et al. (2008), utilising the compounds contained in our on-site gas standard. For the higher $m / z$ range, where no suitable compound was present in our standard, the classical transmission approach of Steinbacher et al. (2004) was adopted using a range of liquid standards. These standards included the higher $\mathrm{m} / \mathrm{z}$ compounds xylene $(\mathrm{m} / \mathrm{z}$ 107) and camphor $(\mathrm{m} / \mathrm{z}, 153)$ and the resulting transmission response was compared with the former approach to yield empirical sensitivities for the higher $\mathrm{m} / \mathrm{z}$ 's. Calculating transmission coefficients empirically undoubtedly increases the level of uncertainty of the volume mixing ratios (vmrs), but this level varies depending upon the approach adopted. The approach of Taipale et al. (2008) is thought to lead to vmrs with an associated uncertainty of $\pm 30 \%$ (e.g. Misztal et al. (2010b)), whereas vmrs calculated using the Steinbacher et al. (2004) approach can vary by as much as $\pm 100 \%$. With this in mind, empirically derived vmrs for the lower $m / z$ range, e.g. acetic acid and MVK+MACR, have a lower level of uncertainty than those in the higher $m / z$ range e.g. $m / z 83$ (hexanals) and $\mathrm{m} / \mathrm{z} 85$ (EVK). The remaining compounds presented in this study were all contained within our gas mixture and therefore sensitivities were calculated directly and the uncertainty much lower.

During OP3-I the multi-component gas standard was not available. Consequently only isoprene could be calibrated directly, using a low mixing ratio gas standard $(4.52 \mathrm{ppbv} \pm 5 \%)$ (see Lee et al., 2006, for details). Subsequent analysis of the two isoprene standards by GC-FID showed less than $2 \%$ difference. Calibration for all other compounds measured during the first campaign was based on the empirically derived instrument specific transmission curve (Steinbacher et al., 2004), relative to isoprene.

\subsection{PTR-MS operation and flux calculations}

Fluxes of individual VOC species were calculated using the virtual disjunct eddy covariance technique (vDEC) (Karl et al., 2002) as implemented previously (Langford et al., 2009, 2010; Davison et al., 2009). In order to provide both flux data and information on the full VOC composition, the PTRMS was programmed to operate in two modes, flux and scan. During the flux mode, 13 protonated masses were targeted with a dwell time of $0.5 \mathrm{~s}$ per mass, as well as the primary ion count (quantified indirectly from $\mathrm{H}_{3}^{18} \mathrm{O}^{+}$at $\mathrm{m} / z 21$ ) and the first water cluster ion count (detected directly as $\mathrm{H}_{3}^{16} \mathrm{O}^{+}$ $\mathrm{H}_{2}^{16} \mathrm{O}^{+}$at $\mathrm{m} / \mathrm{z}$ 37) which were both measured with a $0.1 \mathrm{~s}$ dwell time. This resulted in a total scan cycle time of $6.7 \mathrm{~s}$ and the acquisition of $\sim 224$ data points $(N)$ per 25-min flux averaging period. The remaining $10 \mathrm{~min}$ of each hour were used to obtain basic concentration information across the mass spectrum (21-206 amu, $\mathrm{m} / \mathrm{z}$ resolution $=1 \mathrm{amu})(5 \mathrm{~min})$, and to monitor the instrument background $(5 \mathrm{~min})$, which was subtracted during post processing. The instrument background was monitored by sampling ambient air that had passed through a zero air generator, which comprised a glass tube packed with platinum catalyst powder heated to $200^{\circ} \mathrm{C}$.

Attributing measured ion counts to individual VOC is difficult due to the limitations of the ion-mass filter, which can only resolve ion counts with a resolution of one atomic mass unit. Therefore unambiguous identification of individual 
VOCs is not possible with the PTR-MS instrument and contributions from mass fragments or other compounds with the same integer amu cannot be ruled out. In Table 1 we therefore summarise both the measured masses and the compounds most likely to contribute at each mass, as well as formulae, dwell times, instrument sensitivities and detection limits.

In order to account for the sampling delay induced by the distance between inlet and instrument, and so synchronise the PTR-MS data with that collected by the ultrasonic anemometer, a cross-correlation function of vertical wind velocity $\left(w^{\prime}\right)$ and scalar concentration $\left(\chi^{\prime}\right)$ was used with the peak value chosen automatically over a $25 \mathrm{~s}$ time window. This procedure was applied to each individual $\mathrm{m} / \mathrm{z}$ measured by the PTR-MS. Following this synchronisation, each 25min flux file was then subject to a quality assessment, as described by Langford et al. (2010). Briefly, a two dimensional coordinate rotation was applied. Data were rejected during periods of non-stationarity and when the friction velocity $\left(u_{*}\right)$ fell below $0.15 \mathrm{~m} \mathrm{~s}^{-1}$. The latter criterion resulted in the rejection of approximately $27 \%$ of the collected data, while those that passed these criteria were ranked as either high- or low-quality, based on the exact outcome of the stationarity test. The precision of each individual flux measurement was calculated at the $99.7 \%$ confidence interval following the procedure outlined by Spirig et al. (2005). This value was then used as a proxy for the limit of detection of the flux system and data that fell below this value were discarded. Rejecting data below this threshold ensured that all flux data presented in this manuscript were significantly different from zero.

\subsection{Validity of flux measurements and potential losses}

In order to assess the validity of measurements made, several analyses were undertaken. Firstly, the integral turbulent statistics of the vertical wind velocity were evaluated by comparison of the measured ratio of the standard deviation of vertical wind component to friction velocity $\left(\sigma_{w} / u_{*}\right)$ with values obtained using the model of Foken et al. (2004), which predicts $\sigma_{w} / u_{*}$ for a set of ideal conditions.

Following the assessment criteria used in the FLUXNET program (Foken et al., 2004), over $90 \%$ of the collected data were rated category 6 or better (i.e., suitable for general use) and less than $1 \%$ of the data qualified for rejection with a rank of class 9. This suggests that the turbulence encountered at this site, although light, was sufficiently well developed for the precise and accurate determination of fluxes and that flux measurements at this high measurement height were not adversely influenced by the effects of wake turbulence generated by the tower or surrounding topography (Helfter et al., 2010).

The vDEC flux system was evaluated to establish flux losses due to bandwidth limitation. High frequency flux losses encountered due to the response time of the PTR-MS, which cannot resolve fluctuations in the sub $\sim 0.5 \mathrm{~s}$ range, were estimated from Horst (1997) and found to be negligible, and typically $<2 \%$. In contrast, the low frequency flux losses, arising from insufficient averaging periods, were more significant, as shown by Fig. 1. The $y$ axes in this figure show sensible heat fluxes calculated using averaging periods of increasing length from panels $\mathrm{A}(1 \mathrm{~h})$ to $\mathrm{D}(2.5 \mathrm{~h})$ during the OP3 campaign. The $x$ axes show the same data but the averaging periods are compiled of individual $30 \mathrm{~min}$ data files matched together. A high pass filter was applied to each $30 \mathrm{~min}$ file which ensured fluctuations from eddies with a time period greater than $30 \mathrm{~min}$ could not contribute to the flux measurement (Moncrieff et al., 2004). The slope of the regression between the two sets of fluxes provides an estimate of the flux missed due to the use of a $30 \mathrm{~min}$ averaging period. The results show that eddies with a time period of between 30 and $90 \mathrm{~min}$ increase the flux of sensible heat $(H)$ by $\sim 15 \%$, while eddies with a period of 150 min carried a further $6 \%$ of the flux. Assuming similarity and identical frequency behaviour between sensible heat and VOC fluxes, it is probable that VOC fluxes measured at the GAW site using 25 min averaging periods will underestimate the true surface exchange by $15-20 \%$. This relatively large contribution from low frequency eddies probably reflects our high measurement location and the values we report here are of a similar magnitude to those reported by Langford et al. (2010) for an analysis of data obtained from the comparibly high Telecom Tower in central London. In contrast to this analysis, an investigation into the daytime energy budget closure at this site suggests closure to within $5 \%$ based on 30 min flux values (Helfter et al., 2010). However, since the footprint of the net radiation measurements was not ideal, this closure may be slightly fortuitous.

Additional flux losses may be encountered due to the high relative humidity encountered (60-90\%), which can cause condensation in sample lines, attenuating the signal of water soluble compounds such as methanol. In order to evaluate these losses, latent-heat fluxes $(\lambda E)$ were calculated using the PTR-MS, which was first calibrated using data recorded by a closed path infrared gas analyser (IRGA) ( LI-COR LI-7000, Biosciences, Nebraska, US) in a method similar to that of Ammann et al. (2006). The IRGA sub-sampled directly after the PTR-MS from the same sample tube. PTR-MS $\lambda E$ fluxes were then compared against the measurement of an openpath IRGA (LI-COR LI-7500, Biosciences, Nebraska, US) which was mounted directly below the $75 \mathrm{~m}$ sonic anemometer during the OP3-III campaign (June-July 2008). As the open-path instrument provides an in situ measurement of water vapour concentrations, fluxes calculated using this sensor are not subject to signal damping and therefore a direct comparison with PTR-MS fluxes can provide an estimate of flux losses along the sample line. For a detailed description of the IRGA setup and results, see Siong et al. (2010). 
Table 1. List of compounds measured during the OP3 campaigns, including their formula, dwell time, average sensitivity and detection limit. Detection limits were calculated based on the signal to noise ratio of measured ion counts following Karl et al. (2003) $\left(\mathrm{LOD}=2 \times \sigma_{\text {background }} /\right.$ sensitivity).

\begin{tabular}{|c|c|c|c|c|c|}
\hline $\begin{array}{c}m / z \\
{[\mathrm{amu}]}\end{array}$ & Contributing compound(s) & Formula & $\begin{array}{l}\text { Dwell time } \\
\text { [s] }\end{array}$ & $\begin{array}{l}\text { Average sensitivity } \\
{\left[\mathrm{ncps} \mathrm{ppbv}^{-1}\right]}\end{array}$ & $\begin{array}{l}\text { Limit of Detection } \\
\text { [ppbv] }\end{array}$ \\
\hline 21 & water isotope & $\mathrm{H}_{2}^{18} \mathrm{O}$ & $0.1 \mathrm{~s}$ & - & - \\
\hline 33 & methanol & $\mathrm{CH}_{4} \mathrm{O}$ & $0.5 \mathrm{~s}$ & 11.6 & 1.2 \\
\hline 37 & water cluster & $\left(\mathrm{H}_{2} \mathrm{O}\right)_{2}$ & $0.1 \mathrm{~s}$ & - & - \\
\hline 42 & acetonitrile & $\mathrm{C}_{2} \mathrm{H}_{3} \mathrm{~N}$ & $0.5 \mathrm{~s}$ & 19.6 & - \\
\hline 45 & acetaldehyde & $\mathrm{C}_{2} \mathrm{H}_{4} \mathrm{O}$ & $0.5 \mathrm{~s}$ & 22.8 & 0.1 \\
\hline 59 & $\begin{array}{l}\text { acetone } \\
\text { propanal }\end{array}$ & $\mathrm{C}_{3} \mathrm{H}_{6} \mathrm{O}$ & $0.5 \mathrm{~s}$ & 25.2 & 0.1 \\
\hline 61 & acetic acid & $\mathrm{C}_{2} \mathrm{H}_{4} \mathrm{O}_{2}$ & $0.5 \mathrm{~s}$ & 26.5 & 0.09 \\
\hline 69 & $\begin{array}{l}\text { isoprene } \\
\text { furan }\end{array}$ & $\mathrm{C}_{5} \mathrm{H}_{8}$ & $0.5 \mathrm{~s}$ & 1.6 & 0.2 \\
\hline 71 & $\begin{array}{l}\text { methyl butenol fragment } \\
\text { methyl vinyl ketone } \\
\text { methacrolein }\end{array}$ & $\mathrm{C}_{4} \mathrm{H}_{6} \mathrm{O}$ & $0.5 \mathrm{~s}$ & 27.1 & 0.07 \\
\hline 81 & monoterpene fragment & - & $0.5 \mathrm{~s}$ & 4.0 & 0.04 \\
\hline 83 & $\begin{array}{l}\text { hexanal fragment } \\
\text { cis-3-hexenol fragment }\end{array}$ & - & $0.5 \mathrm{~s}$ & 30.3 & 0.04 \\
\hline 85 & ethyl vinyl ketone & $\mathrm{C}_{5} \mathrm{H}_{8} \mathrm{O}$ & $0.5 \mathrm{~s}$ & 30.3 & 0.06 \\
\hline 137 & monoterpenes & $\mathrm{C}_{10} \mathrm{H}_{16}$ & $0.5 \mathrm{~s}$ & 3.7 & 0.04 \\
\hline 149 & estragole & $\mathrm{C}_{10} \mathrm{H}_{12} \mathrm{O}$ & $0.5 \mathrm{~s}$ & - & - \\
\hline 205 & sesquiterpenes & $\mathrm{C}_{15} \mathrm{H}_{24}$ & $0.5 \mathrm{~s}$ & - & - \\
\hline
\end{tabular}

Figure 2 shows $\lambda E$ measured by PTR-MS and open-path IRGA over an 11-day period. Measured fluxes agree reasonably well $\left(R^{2}=0.56, p=<0.0001\right)$, but on average PTRMS fluxes are lower, suggesting a typical flux loss of around $<17 \%$. This flux loss is much larger than direct comparisons between open and closed path IRGA $\lambda E$ fluxes, which showed just a $1 \%$ underestimation, again resulting from the long sample line $\left(R^{2}=0.93, p=<0.0001, y=0.9916 x-0.9632\right)$. It should be noted that the PTR-MS $\lambda E$ fluxes are in fact sampled disjunctly, which, when coupled with the indirect calibration against the closed-path IRGA may account for the larger disparity between the measurement systems.

The high measurement location of $75 \mathrm{~m}$ atop a hill also introduces the potential for flux divergence for the more reactive compounds such as isoprene, caused by changes in both convective mixing and isoprene chemistry across the day. We therefore estimated the effect of both isoprene chemistry and transport on the measurements made at our site.

In order to approximate the time taken between isoprene emission and detection by our measurement system, we estimated the mixing time to our measurement location using the convective velocity timescale $\left(\tau_{\text {mix }}\right)$, calculated as a function of time of day.

$$
\tau_{\operatorname{mix}}=\frac{z}{w_{*}}
$$

where $z$ is the measurement height which was between 100 and $150 \mathrm{~m}$ above the average canopy top, here we use an arbitrary value of $125 \mathrm{~m}$ and $w_{*}$ is equal to:

$w_{*}=\left[\frac{g z}{T_{v}} F_{H}\right]^{\frac{1}{3}}$

where, $g$ is acceleration due to gravity $\left(9.81 \mathrm{~m} \mathrm{~s}^{-2}\right), T_{v}$ is potential temperature, and $F_{H}$ is the kinematic heat flux. The isoprene lifetime $\left(\tau_{\text {chem }}\right)$ was calculated using the isoprene $+\mathrm{OH}$ rate coefficient as a function of the ambient temperature (measured at $30 \mathrm{~m}$ ) and the $\mathrm{OH}$ concentration which was directly measured at a height of $5 \mathrm{~m}$ at the base of the GAW tower (Whalley et al., 2010). Figure 3 shows $\tau_{\text {chem }}$ (blue line) and $\tau_{\text {mix }}$ (red line) which follow a similar pattern, with shorter mixing times and isoprene lifetimes occurring in the late morning and increasing steadily throughout the afternoon. The net effect of these two processes on our measurements of isoprene was calculated using the Damköhler number (black line),

$D a=\frac{\tau_{\text {mix }}}{\tau_{\text {chem }}}$

A Damköhler number of 1 or greater would indicate transport times to exceed reaction times resulting in a total loss of isoprene. Figure 3 shows the $D a$ number to follow a distinct diurnal pattern, with the largest isoprene losses occurring in the late morning and indicating a maximum $2 \%$ loss 

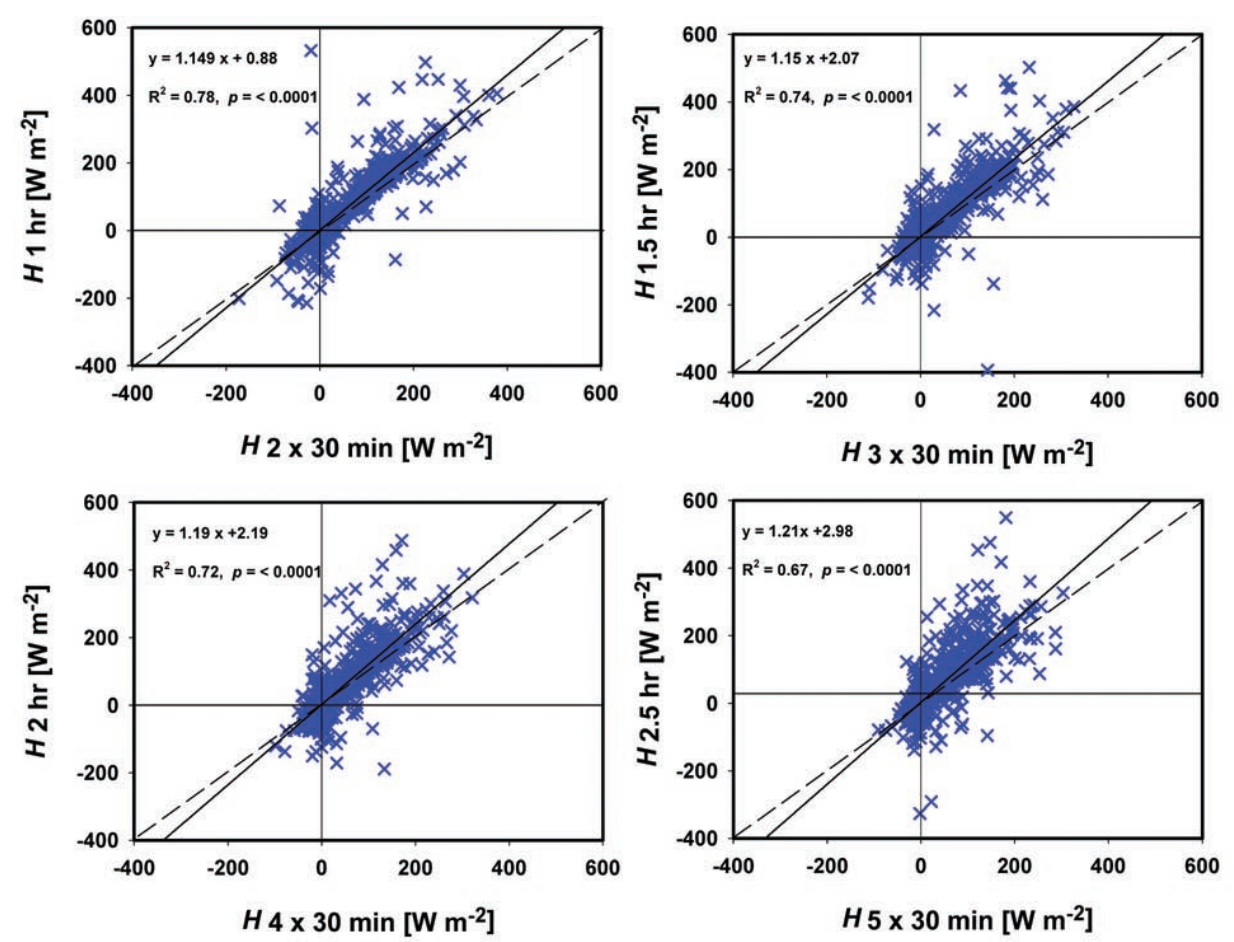

Fig. 1. An analysis of low frequency flux losses for sensible heat flux data $(H)$ collected at the GAW site during the OP3 campaign. Solid line shows the best linear fit and dashed line represents the 1:1 line.
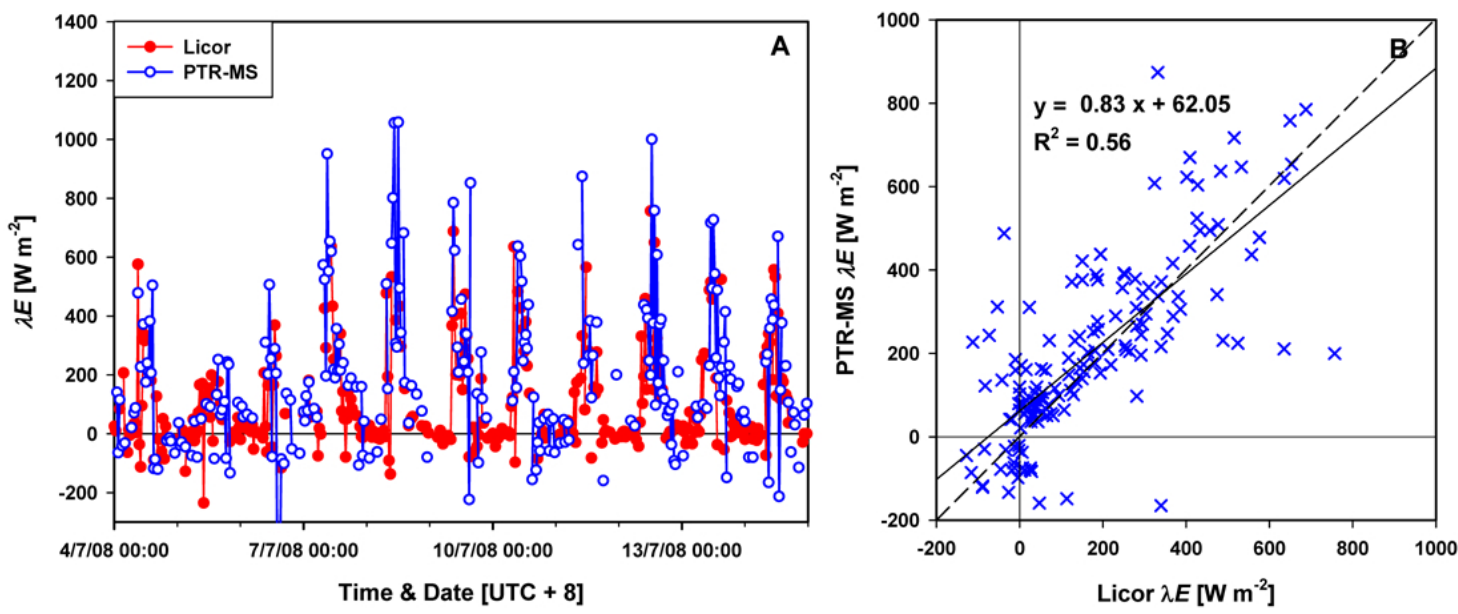

Fig. 2. (A) Latent heat fluxes measured at the GAW site during the period of 4-14 July by open path IRGA (LICOR - 7500) and PTR-MS. PTR-MS water vapour measurements recorded as $m / z, 37$ were calibrated against a closed path IRGA (LICOR - 7000) which sampled from the same $70 \mathrm{~m}$ sample line as the PTR-MS. (B) indicates the amount of flux lost due to attenuation along the long sample inlet and can be used to estimate a worst case scenario of VOC flux losses.

of isoprene. It should be noted that this calculation only considers the chemical loss after the compounds exit the canopy top and further chemical processing is likely to occur before emissions escape the canopy.

These analyses suggest that VOC fluxes measured at this site are underestimated due to a combination of insufficient averaging periods, flux divergence and some signal attenuation along the $\sim 90 \mathrm{~m}$ sampling line. No corrections for these flux losses were applied to the data presented in this study. The estimated losses are small compared to the differences between measured and estimated emissions (Sect. 3.2.2, below). 


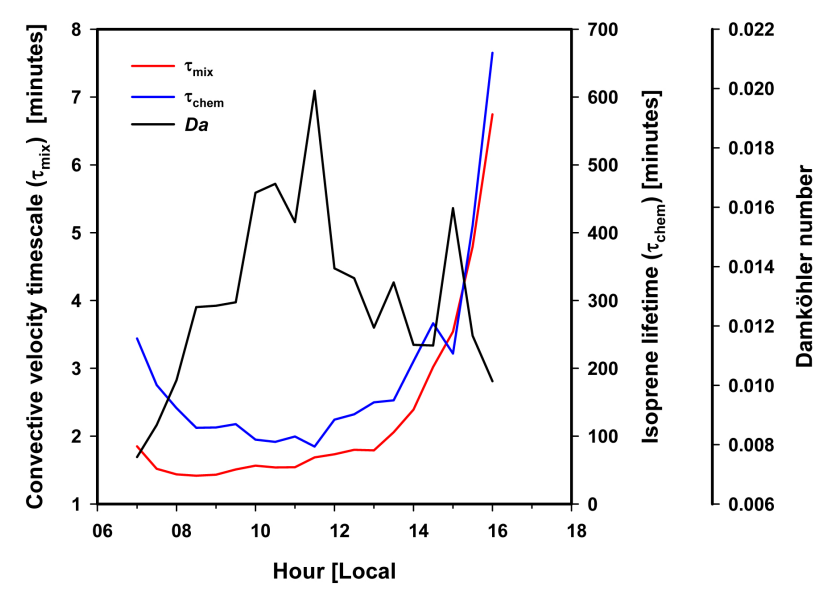

Fig. 3. The average boundary layer convective mixing velocity timescale $\left(\tau_{\mathrm{mix}}\right)$ and isoprene lifetime $\left(\tau_{\mathrm{chem}}\right)$ for the period 221 July 2008 above a tropical rainforest. The Damköhler number (black line) indicates the amount of isoprene that would be lost to chemical reaction before detection by our measurement system, which was located at $100-150 \mathrm{~m}$ above the forest canopy top. Because the GAW tower is located on a hill it is not possible to give a more precise measurement height.

\section{Results and discussion}

\subsection{Ambient BVOC mixing ratios}

Figure 4 shows the average diurnal mixing ratios of the nine VOCs measured during the OP3 campaign and the results are summarised in Table 2a. During the daytime, mixing ratios for each compound were always above the calculated limit of detection, with the exception of methanol and $\mathrm{m} / \mathrm{z}$ 's 83 and 85 , which we tentatively ascribe to hexanal and/or cis3-hexenol, and ethyl vinyl ketone (EVK), respectively. For methanol, instrument background counts were generally high but of a fairly constant amplitude. Consequently the detection limit for methanol was relatively high despite the high sensitivity for this compound obtained in calibrations. Although our concentration measurements of methanol were always close to or below the detection limit, they are of a similar magnitude to measurements made by GC-FID during the campaign (Jones et al., 2010), hence their inclusion here. Although estragole (Misztal et al., 2010b) and sesquiterpenes were both targeted during the two campaigns, neither compound was detected by our system.

Isoprene was the second most abundant compound observed after methanol, accounting for approximately $30 \%$ (as compound) of the total measured species. Mixing ratios ranged between 0.17 and $3.4 \mathrm{ppbv}$ with an average of 1.3 ppbv. Methacrolein (MACR) and methyl vinyl ketone (MVK), which are measured at the same atomic mass unit (amu) by the PTR-MS and consequently presented as the sum of the two (MACR+MVK), ranged between 0.05 and
$0.67 \mathrm{ppbv}$, with an average value of $0.25 \mathrm{ppbv}$. Isoprene oxidation is the only known source of MACR and MVK; hence, the ratio of (MACR+MVK) to isoprene can provide an indication of the extent of isoprene oxidation. Average ratios of 0.16 and 0.22 were observed for the first and second campaigns, respectively. These findings are similar to observations by Kesselmeier et al. (2002) who reported abovecanopy ratios in Amazonia of 0.23 and 0.3 during the wet and dry seasons respectively. Similarly, Kuhn et al. (2007) reported a ratio of 0.3 for dry season measurements above Amazonia. Following the method of Karl et al. (2004), the average time taken between isoprene emission and detection by our system was estimated at between 16-22 min (based on the average midday [MVK+MACR]/[isoprene] ratio and an assumed atmospheric lifetime for isoprene of $100 \mathrm{~min}$ ). Accordingly, isoprene mixing ratios were estimated to have originated from within a maximum footprint length of 2.8 $3.9 \mathrm{~km}$ (based on an average wind speed of $3 \mathrm{~m} \mathrm{~s}^{-1}$ ). This is slightly larger than the approximate footprint calculations reported by Helfter et al. (2010) for OP3 under unstable daytime conditions. This difference probably reflects the fact that isoprene emissions may take some time to exit the canopy and therefore undergo some chemical processing before exiting the canopy.

Figure 5 shows the [MVK+MACR]-to-[isoprene] ratio over the course of a typical day. The ratio has a distinct pattern, with a sharp decline observable at dawn as the nocturnal ratio decreased from 0.26 to 0.1 in the early morning. This relates to the response of the canopy to the increasing light and temperature which drives the isoprene emissions and a decrease in the transport time between canopy and the measurement height. As the isoprene emissions are transported away from the canopy they react to form more MVK+MACR which gradually accumulates in the boundary layer and thus the ratio increases steadily throughout the day before reaching a stable nocturnal maximum, when the isoprene emission and photochemistry shut off.

Monoterpene mixing ratios were relatively low, ranging between 0.02 and $0.47 \mathrm{ppbv}$ with an average of $0.17 \mathrm{ppbv}$, which is approximately $50 \%$ lower than the average of measurements made above Amazonia (Karl et al., 2007). Due to limitations of the PTR-MS approach, the measurement can only measure total monoterpene concentrations as this concentration is derived from a fragment that is common to the different compounds. Measurements of speciated monoterpenes were made by a dual-channel gas chromatograph with a flame ionisation detector (GC-FID) and are reported elsewhere (Jones et al., 2010). This instrument sampled air from an inlet located $5 \mathrm{~m}$ above ground level at the base of the GAW tower with a $1 \mathrm{~h}$ time resolution. Although the PTRMS and GC-FID were separated vertically by $70 \mathrm{~m}$ and therefore sampled different air masses, the GC-FID results indicate that the monoterpene emissions at this site were dominated by $\gamma$-terpinene and camphene (Jones et al., 2010). 

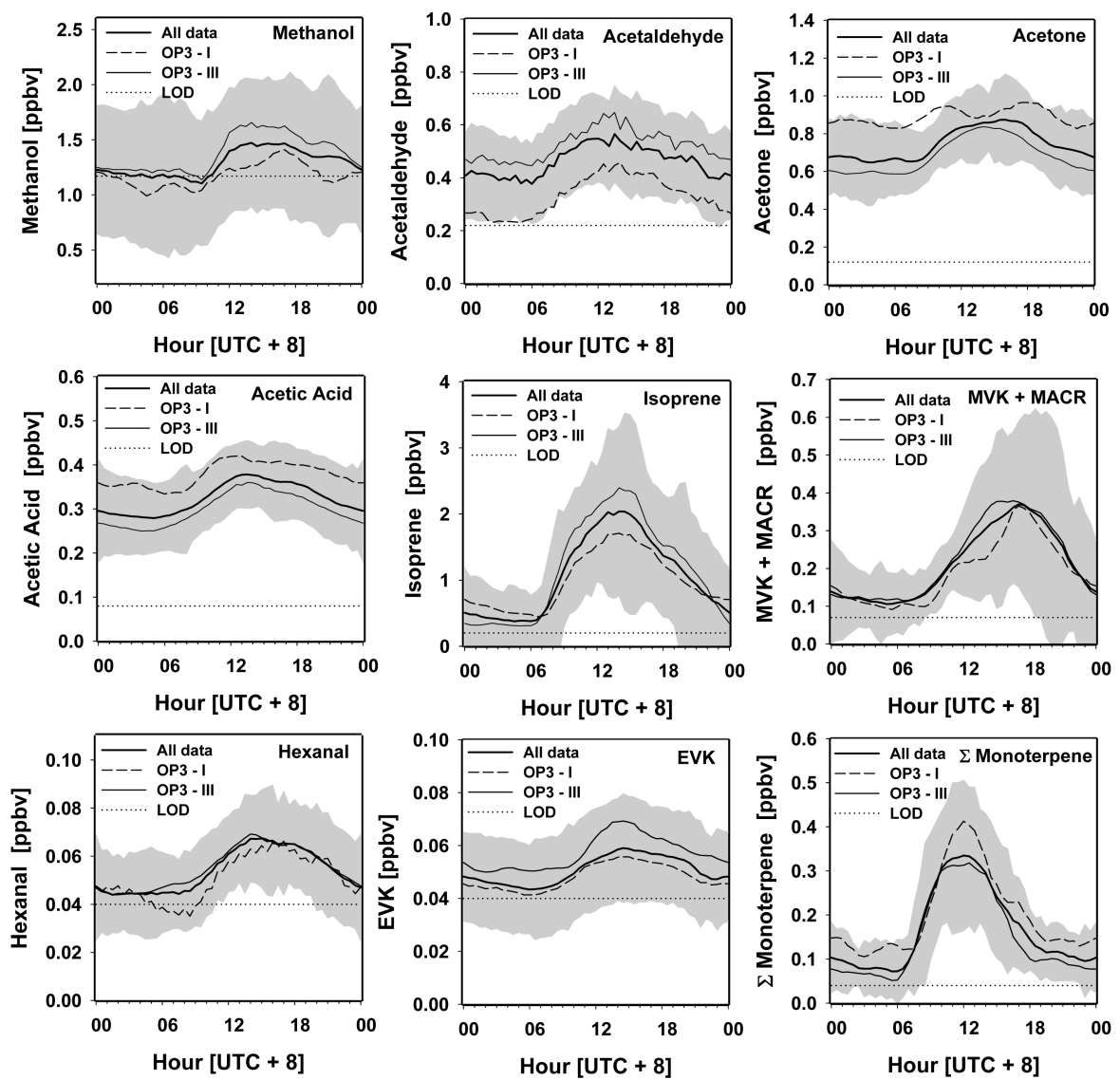

Fig. 4. Average diurnal profiles of VOC mixing ratios measured during the two intensive OP3 field campaigns which took place between 20 April-7 May (OP3-I) and 20 June and 20 July (OP3-III), 2008. Grey error bands show \pm 1 standard deviation of averaged hourly values and dotted lines show the limit of detection ( $\mathrm{LOD}=2 \times \sigma_{\text {background }} /$ sensitivity).

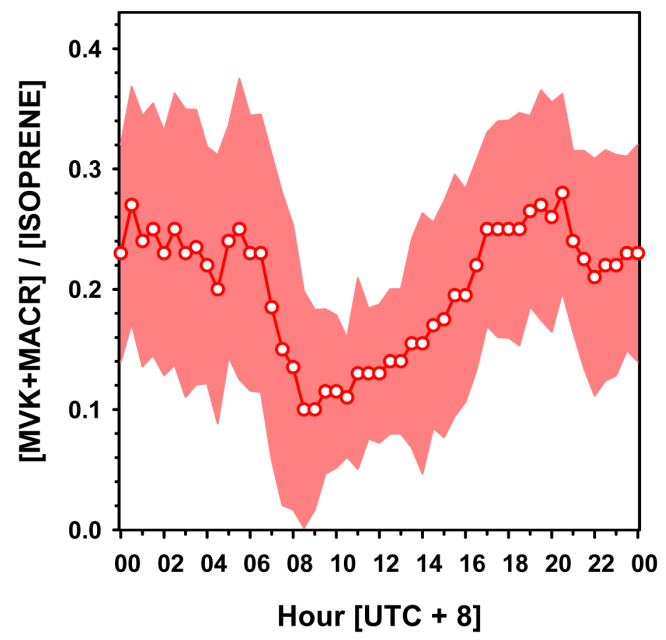

Fig. 5. Average diurnal profile of the MVK+MACR:isoprene ratio during OP3-III.
Acetone mixing ratios ranged between $0.46-1.10 \mathrm{ppbv}$, with an afternoon maximum which typically occurred 1 to $3 \mathrm{~h}$ after the maximum in isoprene mixing ratios. Our measured values were similar to those reported above a tropical rainforest in Costa Rica (Karl et al., 2004) and approximately half of those reported above regions of Amazonia (Karl et al., 2007; Williams et al., 2001). Mixing ratios of acetone were slightly higher during OP3-I than OP-III which was also the case for acetic acid. Acetic acid mixing ratios ranged between $0.22-0.5 \mathrm{ppbv}$, but in contrast to the trend in acetone, peak values occurred in the early afternoon, closely following the diurnal pattern in ambient air temperature. This close relationship with temperature is typical for this compound, particularly in remote locations (Martin et al., 1991; Khare et al., 1999), but the observed values are slightly lower than those reported elsewhere (Kuhn et al., 2002; Karl et al., 2004). 
Table 2a. Summary of VOC mixing ratios (ppbv) measured during the two intensive OP3 campaigns.

\begin{tabular}{|c|c|c|c|c|c|c|c|c|c|}
\hline & Isoprene & $\Sigma$ Monoterpene & Methanol & Acetaldehyde & Acetone & MVK+MACR & Acetic acid & Hexanal & EVK \\
\hline \multicolumn{10}{|c|}{ OP3 I (Wet) } \\
\hline Mean & 1.1 & 0.24 & 1.2 & 0.36 & 0.91 & 0.23 & 0.40 & 0.05 & 0.05 \\
\hline Median & 0.95 & 0.22 & 1.2 & 0.34 & 0.90 & 0.18 & 0.38 & 0.05 & 0.05 \\
\hline \multicolumn{10}{|c|}{ Percentiles } \\
\hline-95 th & 2.8 & 0.55 & 1.9 & 0.64 & 1.3 & 0.67 & 0.58 & 0.09 & 0.07 \\
\hline-5 th & 0.28 & 0.06 & 0.42 & 0.16 & 0.50 & 0.04 & 0.28 & 0.02 & 0.04 \\
\hline$\sigma$ & 0.80 & 0.15 & 0.46 & 0.14 & 0.22 & 0.20 & 0.09 & 0.02 & 0.01 \\
\hline$n$ & 746 & 744 & 746 & 751 & 704 & 745 & 755 & 703 & 751 \\
\hline \multicolumn{10}{|c|}{ OP3 III (Early Dry) } \\
\hline Mean & 1.4 & 0.14 & 1.5 & 0.54 & 0.70 & 0.26 & 0.31 & 0.06 & 0.06 \\
\hline Median & 1.1 & 0.10 & 1.4 & 0.52 & 0.68 & 0.19 & 0.30 & 0.06 & 0.06 \\
\hline \multicolumn{10}{|c|}{ Percentiles } \\
\hline-95 th & 3.6 & 0.44 & 2.7 & 0.84 & 0.99 & 0.67 & 0.43 & 0.09 & 0.10 \\
\hline-5 th & 0.12 & 0.05 & 0.48 & 0.31 & 0.45 & 0.05 & 0.20 & 0.03 & 0.03 \\
\hline$\sigma$ & 1.2 & 0.15 & 0.67 & 0.16 & 0.16 & 0.20 & 0.07 & 0.02 & 0.02 \\
\hline$n$ & 1269 & 1290 & 1252 & 1369 & 1364 & 1374 & 1372 & 1382 & 1378 \\
\hline \multicolumn{10}{|c|}{ OP3 All data } \\
\hline Mean & 1.3 & 0.18 & 1.4 & 0.48 & 0.77 & 0.25 & 0.34 & 0.06 & 0.06 \\
\hline Median & 1.0 & 0.15 & 1.3 & 0.47 & 0.75 & 0.19 & 0.33 & 0.06 & 0.05 \\
\hline \multicolumn{10}{|c|}{ Percentiles } \\
\hline-95 th & 3.4 & 0.48 & 2.5 & 0.78 & 1.1 & 0.67 & 0.50 & 0.09 & 0.09 \\
\hline-5 th & 0.17 & 0.02 & 0.46 & 0.22 & 0.46 & 0.05 & 0.22 & 0.03 & 0.03 \\
\hline$\sigma$ & 1.1 & 0.16 & 0.62 & 0.18 & 0.21 & 0.20 & 0.09 & 0.02 & 0.02 \\
\hline$n$ & 2015 & 2034 & 1999 & 2120 & 2068 & 2119 & 2127 & 2085 & 2129 \\
\hline
\end{tabular}

Table 2b. Summary of VOC fluxes $\left(\mathrm{mg} \mathrm{m}^{-2} \mathrm{~h}^{-1}\right)$ measured during the two intensive OP3 campaigns.

\begin{tabular}{|c|c|c|c|c|c|c|c|c|c|}
\hline & Isoprene & $\Sigma$ Monoterpene & Methanol & Acetaldehyde & Acetone & MVK+MACR & Acetic acid & Hexanal & EVK \\
\hline \multicolumn{10}{|c|}{ OP3 I (Wet) } \\
\hline Mean & 0.54 & 0.15 & -0.02 & 0.01 & 0.007 & -0.002 & -0.005 & 0.004 & 0.004 \\
\hline Median & 0.22 & 0.11 & -0.05 & 0.02 & 0.009 & -0.005 & -0.006 & 0.006 & 0.005 \\
\hline \multicolumn{10}{|c|}{ Percentiles } \\
\hline-95 th & 2.2 & 0.62 & 0.30 & 0.11 & 0.12 & 0.08 & 0.05 & 0.05 & 0.05 \\
\hline-5 th & -0.12 & -0.10 & -0.34 & -0.08 & -0.09 & -0.098 & -0.061 & -0.45 & -0.035 \\
\hline$\sigma$ & 0.82 & 0.22 & 0.21 & 0.06 & 0.065 & 0.055 & 0.036 & 0.032 & 0.025 \\
\hline$n$ & 373 & 329 & 421 & 416 & 417 & 461 & 421 & 406 & 406 \\
\hline \multicolumn{10}{|c|}{ OP3 III (Early Dry) } \\
\hline Mean & 1.2 & 0.29 & -0.04 & 0.004 & 0.002 & -0.002 & -0.003 & 0.003 & 0.002 \\
\hline Median & 0.76 & 0.21 & -0.08 & 0.006 & 0.02 & 0.003 & -0.01 & 0.005 & 0.004 \\
\hline \multicolumn{10}{|c|}{ Percentiles } \\
\hline-95 th & 4.0 & 0.92 & 0.51 & 0.13 & 0.12 & 0.091 & 0.058 & 0.034 & 0.032 \\
\hline-5 th & -0.38 & -0.10 & -0.60 & -0.12 & -0.081 & -0.12 & -0.059 & -0.027 & -0.03 \\
\hline$\sigma$ & 1.4 & 0.37 & 0.35 & 0.084 & 0.065 & 0.072 & 0.004 & 0.021 & 0.021 \\
\hline$n$ & 578 & 550 & 622 & 667 & 702 & 739 & 672 & 644 & 647 \\
\hline \multicolumn{10}{|c|}{ OP3 All data } \\
\hline Mean & 0.93 & 0.24 & -0.033 & 0.007 & 0.012 & -0.002 & -0.038 & 0.003 & 0.003 \\
\hline Median & 0.46 & 0.16 & -0.063 & 0.014 & 0.014 & -0.002 & -0.008 & 0.005 & 0.004 \\
\hline \multicolumn{10}{|c|}{ Percentiles } \\
\hline-95 th & 3.7 & 0.84 & 0.46 & 0.12 & 0.12 & 0.083 & 0.058 & 0.042 & 0.04 \\
\hline-5 th & -0.28 & -0.11 & -0.54 & -0.11 & -0.084 & -0.11 & -0.06 & -0.035 & -0.033 \\
\hline$\sigma$ & 1.3 & 0.33 & 0.3 & 0.073 & 0.065 & 0.066 & 0.037 & 0.026 & 0.023 \\
\hline$n$ & 951 & 879 & 1043 & 1083 & 1119 & 1200 & 1093 & 1050 & 1053 \\
\hline
\end{tabular}




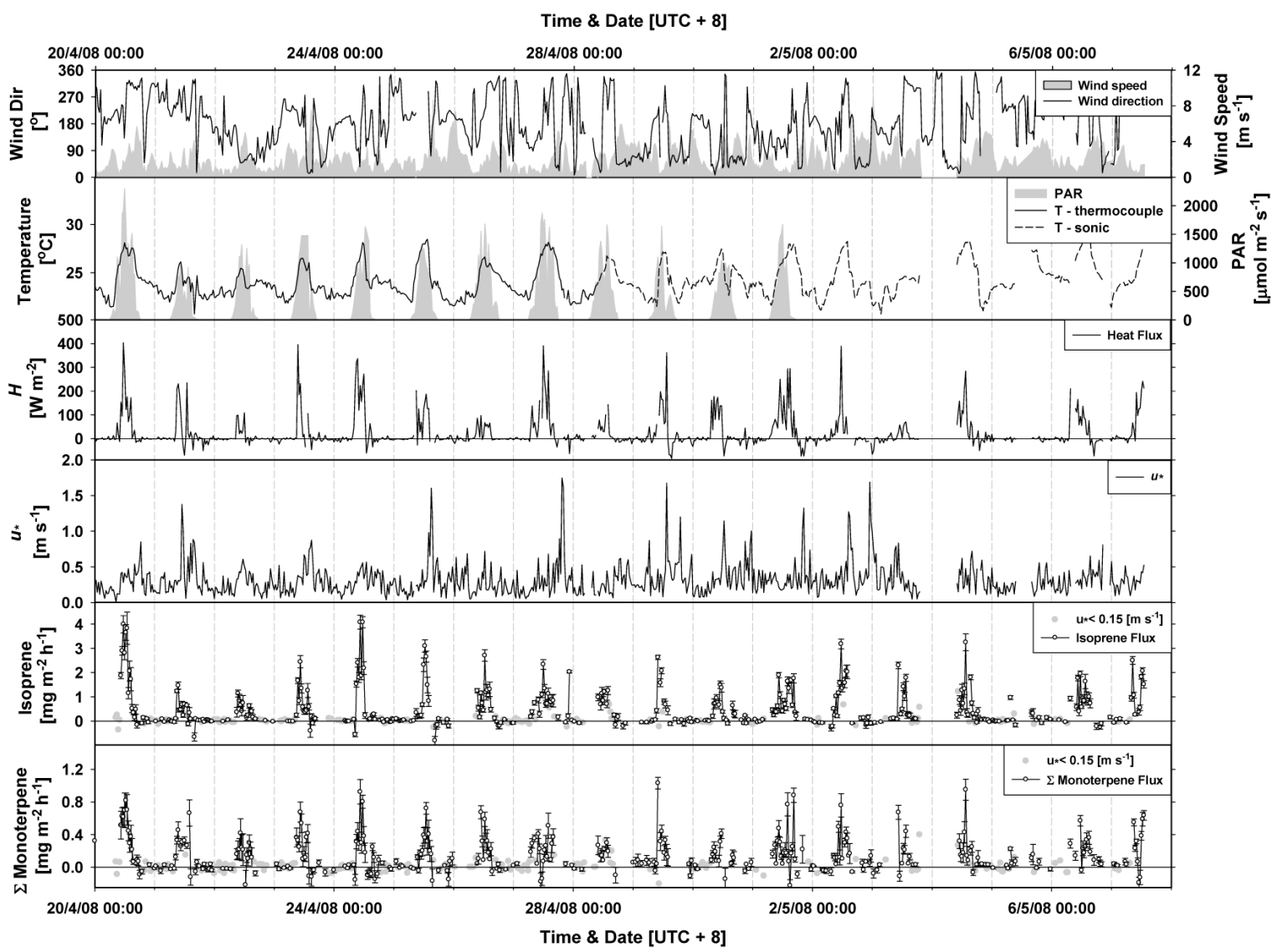

Fig. 6a. Summary of the meteorology and main VOC fluxes during the first intensive OP3 field campaign (OP3 - I) which took place during April and May, 2008. Wind speed and wind direction measurements were recorded by a senor (WXT-510 Weather Transmitter, Vaisala) situated at $75 \mathrm{~m}$ on the GAW tower. Temperature was recorded at $30 \mathrm{~m}$ by an aspirated thermocouple and sonic anemometer, PAR was measured from the roof of the GAW laboratory and sensible heat, friction velocity and VOC fluxes were all measured from the $75 \mathrm{~m}$ platform of the GAW tower. VOC flux data recorded during periods of low turbulence $\left(u_{*}<0.15 \mathrm{~m} \mathrm{~s}^{-1}\right)$ were rejected from the final analysis, but are shown here as grey circles.

\subsection{Surface-layer VOC fluxes}

\subsubsection{Isoprene and monoterpene surface-layer fluxes}

Figures $6 \mathrm{a}$ and $6 \mathrm{~b}$ show measured isoprene and total monoterpene fluxes relative to the meteorological drivers light, temperature, wind speed/direction, frictional velocity and sensible heat flux, for both measurement phases and their statistics are summarised in Table $2 \mathrm{~b}$. During these periods, midday (10:00-14:00) temperature (at $30 \mathrm{~m}$ above ground) ranged between $23-28^{\circ} \mathrm{C}$, and photosynthetically active radiation (PAR) between $336-2027 \mu \mathrm{mol} \mathrm{m}^{-2} \mathrm{~s}^{-1}$, whereas at night, temperatures fell to $22-24^{\circ} \mathrm{C}$. Sensible heat fluxes were positive during the day, ranging between 200 and $400 \mathrm{~W} \mathrm{~m}^{-2}$, with occasional troughs associated with convective cloud cover and rain events, as clearly seen on both 30 June and 5 July. Wind speed and friction velocities varied between $0.6-4.7 \mathrm{~m} \mathrm{~s}^{-1}$ and $0.06-0.52 \mathrm{~m} \mathrm{~s}^{-1}$ (5th-95th percentiles), with particularly low values of both recorded at night. Accordingly, VOC fluxes were generally only observed between 09:00 and 17:00 and not at night.

Previous leaf-level measurements of monoterpenes made in this region have shown temperature-dependent emissions from some dipterocarp tree species (Dryanobalanops lanceolata) (S. M. Owen, personal communication, 2010). These emissions were thought to originate from damage to the cuticular wax caused by herbivory and because the volatilisation of monoterpenes is dependent upon the ambient air temperature, some emissions may be expected at night time. However, during the night the measurement platform became de-coupled from the canopy below, as observed from nocturnal cloud formation at the canopy top, below the measurement height, and validated through LIDAR measurements of the mixed layer height (Pearson et al., 2010). Subsequently, any nocturnal emissions could not be captured by our measurement system. As part of the OP3-III field campaign, Ryder et al. (2010) utilised a second PTR-MS in conjunction with an automated winch system to measure vertical 


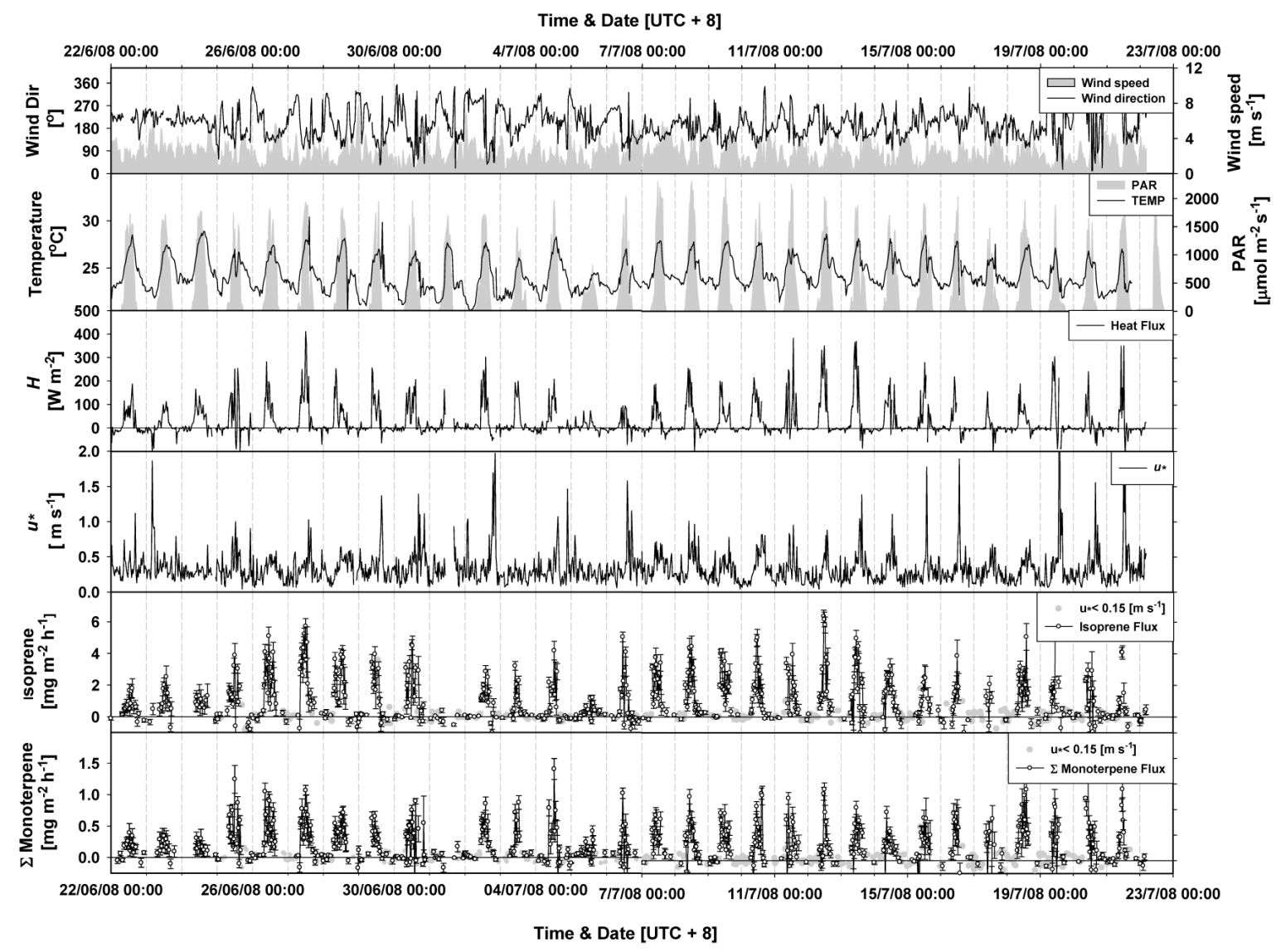

Fig. 6b. Summary of the meteorology and main VOC fluxes during the second intensive OP3 field campaign (OP3 - III) which took place during June and July, 2008. Measurement instrumentation as above. VOC flux data recorded during periods of low turbulence $\left(u_{*}<0.15 \mathrm{~m} \mathrm{~s}^{-1}\right)$ were rejected from the final analysis, but are shown here as grey circles.

profiles $(1 \mathrm{~m}-32 \mathrm{~m})$ of VOC mixing ratios within the forest canopy. The targeted compounds included isoprene and monoterpenes and their source/sink distributions were derived using inverse Lagrangian modelling. These data did not show build up of either isoprene or monoterpenes inside the canopy during the night and indicate that dark emissions were negligible (Ryder et al., 2010). In contrast, early morning emissions of both isoprene and monoterpenes which were driven by the rising sun and accumulated in the still shallow nocturnal boundary layer, were occasionally observed as large spikes at around 08:00-09:00 during the break up of this stable air. The LIDAR measurements confirm that after sunrise the boundary layer quickly expanded. Therefore little of the daytime fluxes were lost due to de-coupling from the canopy.

Emissions of isoprene were the largest of all the measured VOCs, with an average midday flux (10:00-14:00 LT) of $1.9 \mathrm{mg} \mathrm{m}^{-2} \mathrm{~h}^{-1}$ for the entire 48-day period. This value represented approximately $80 \%$ (as carbon) of all measured non-methane BVOC emissions from the forest canopy, with the remaining $20 \%$ accounted for by emissions of to- tal monoterpenes (18\% as carbon) and oxygenated VOCs (OVOC) (2\% as carbon), including methanol, acetone and acetaldehyde - see Sect. 3.2.3. The mean integrated daily flux of isoprene was $6.0 \mathrm{mg} \mathrm{m}^{-2} \mathrm{~d}^{-1}$ and $12.9 \mathrm{mg} \mathrm{m}^{-2} \mathrm{~d}^{-1}$ respectively, for the OP3-I and OP3-III campaigns with an average of $10.5 \mathrm{mg} \mathrm{m}^{-2} \mathrm{~d}^{-1}$ for all collected data (approximately $500 \mathrm{~h}$ of data collected over 48 days). Here, missing night-time data were gap-filled with zero fluxes, consistent with the light-sensitivity of the isoprene emissions. The mean integrated daily fluxes for each phase are statistically different at the $95 \%$ level (two-tailed t-test). The observed increase in emission rates between the two campaigns was consistent with a difference in integrated ambient air temperature $\left(0.3{ }^{\circ} \mathrm{C}\right)$ and PAR $\left(3549 \mu \mathrm{mol} \mathrm{m}^{-2} \mathrm{~s}^{-1}\right.$ PAR $)$ for the average day, and normalising these emissions to standard conditions $\left(30^{\circ} \mathrm{C}\right.$ and $\left.1000 \mu \mathrm{mol} \mathrm{m}{ }^{-2} \mathrm{~s}^{-1} \mathrm{PAR}\right)$, using the algorithms of Guenther et al. (2006) described in the next section, reduced the difference in standard emission rates between the two campaigns to within 6\%. A recent study has suggested that isoprene-emitting vegetation in Amazonia experiences a wide-scale leaf flushing which promotes new growth in 

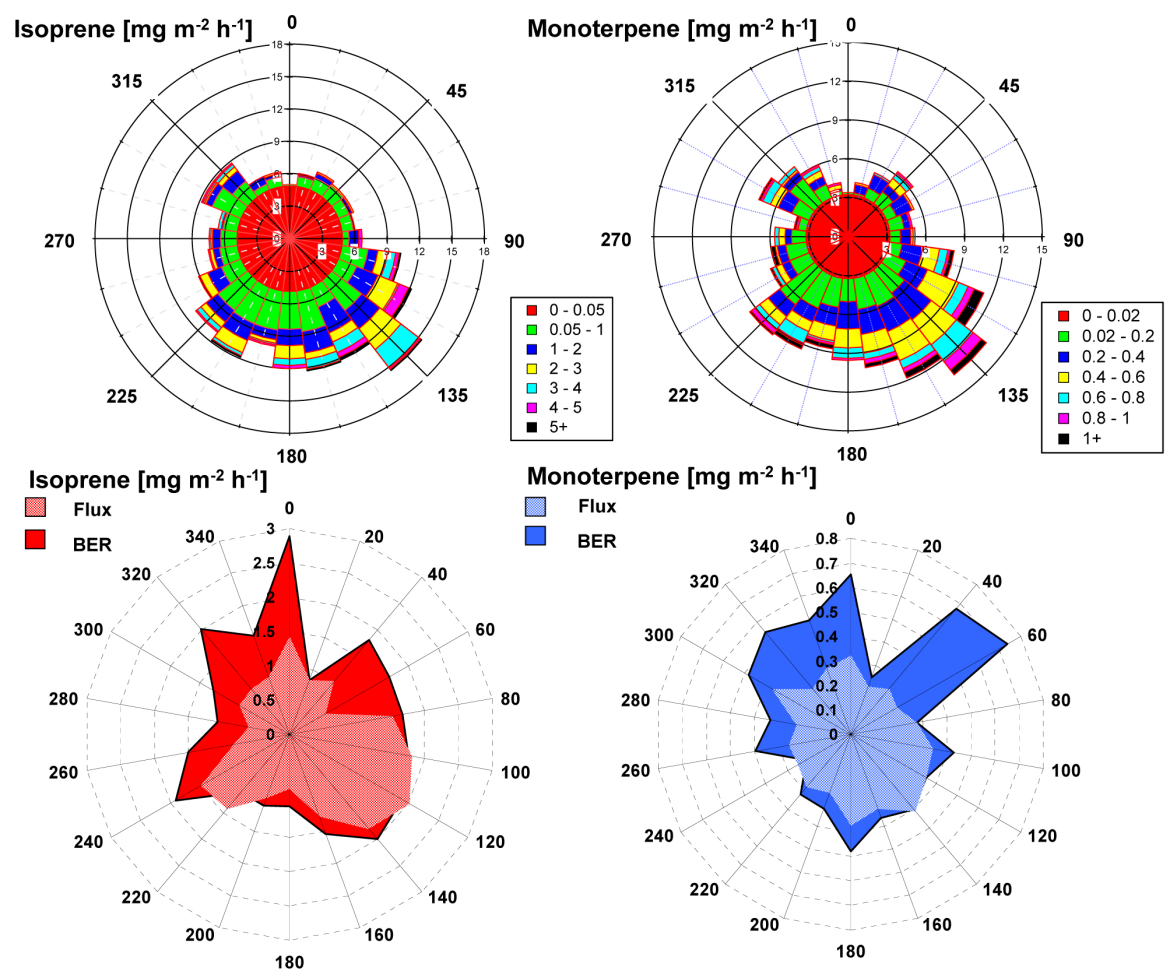

Monoterpene [ $\mathrm{mg} \mathrm{m}^{-2} \mathrm{~h}^{-1}$ ]

$\square \quad$ Flux

BER

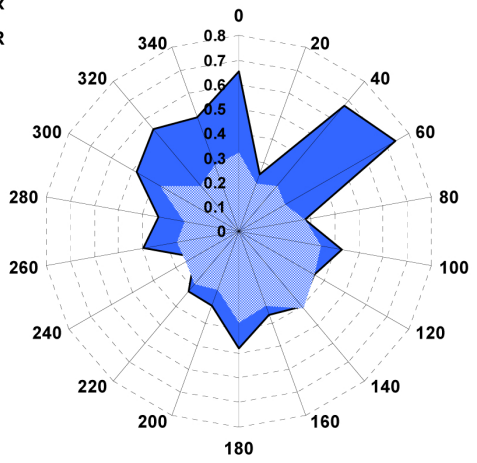

Fig. 7. Wind roses of isoprene and monoterpene fluxes (top) measured during the two OP 3 campaigns. The bottom plots show the same raw flux data (light shading) and the base emission rate (solid shading) which is the raw flux normalised to standard conditions $\left(30{ }^{\circ} \mathrm{C}(\mathrm{Canopy}\right.$ temperature), $1000 \mu \mathrm{mol} \mathrm{m}^{-2} \mathrm{~s}^{-1}$ ) using the light and temperature algorithms from the MEGAN model (Guenther et al., 2006).

preparation for the coming dry season, resulting in an annual shutdown of isoprene emissions (Barkley et al., 2009). Similarly, Müller et al. (2008) have shown that isoprene emissions can be between 2-5 times lower during the wet season. Seasonality in Borneo is much less marked than in Amazonia; and our measurements showed no evidence of a similar process occurring at this site.

The average daytime ratio of monoterpene to isoprene fluxes was $0.23 \pm 0.3$ (standard deviation) and remained relatively constant throughout the day, including the period when early morning emissions were vented from the still shallow nocturnal boundary layer. This relative constancy suggests that nocturnal, light-independent emissions of monoterpenes are negligible at this site, which is consistent with Owen et al. (2002) and with the in-canopy profile measurements made by Ryder et al. (2010) who did not detect monoterpene emissions from the darker understorey during the day or night-time build-ups inside the canopy. Guenther et al. (2008) summarise the monoterpene:isoprene emission ratios observed in other tropical forests, with values typically found to be $\sim 0.15$.

Polar plots of isoprene and monoterpene fluxes shown in Fig. 7 (top two panels), indicate that canopy emissions were spatially very heterogeneous, with observed fluxes strongly skewed towards the south-east. Analysis of polar plots for temperature and PAR shows a similar south- east skew. This direction-dependent temperature effect was accounted for by normalising measured fluxes to give the base emission rate (BER; $30^{\circ} \mathrm{C}$ (canopy temperature) and $1000 \mu \mathrm{mol} \mathrm{m}^{-2} \mathrm{~s}^{-1}$ PAR). The resulting polar plots of BER (Fig. 7, bottom two panels) were less pronounced in the south east, but still showed considerable variability in emission rates between wind sectors, with values ranging between 0.8 and $2.9 \mathrm{mg} \mathrm{m}^{-2} \mathrm{~h}^{-1}$ for isoprene and between 0.2 and $0.7 \mathrm{mg} \mathrm{m}^{-2} \mathrm{~h}^{-1}$ for monoterpenes. Average BERs during the OP3 campaigns were 1.6 and $0.46 \mathrm{mg} \mathrm{m}^{-2} \mathrm{~h}^{-1}$ for isoprene and monoterpenes, respectively.

During the period between OP3-I and OP3-III Owen et al. (2010) made leaf-level measurements of isoprene and monoterpene emissions from the 25 most dominant over- and understorey tree species located within the flux footprint of the GAW tower. These species were sampled in situ and in triplicate using 3 controlled environment leaf cuvettes, which were set to $30^{\circ} \mathrm{C}$ and a PAR value of either 500 or $1000 \mu \mathrm{mol} \mathrm{m}^{-2} \mathrm{~s}^{-1}$, depending on whether the leaves were shaded or sunlit. The inflowing air was scrubbed to remove pre-existing VOCs whereas the $\mathrm{CO}_{2}$ and humidity were allowed to follow the ambient conditions. The outflowing air was sampled onto tubes packed with Tenax and Carbotrap and were stored at $4{ }^{\circ} \mathrm{C}$ until analysis by GC-MS could take place in the UK. These measurements contributed to a larger database of SE Asian forest emission rates compiled 
Table 3. Isoprene and monoterpene flux measurements from the world's tropical forests and their typical ratios (monoterpene/isoprene). All values are in units of $\mathrm{mg} \mathrm{C} \mathrm{m}^{-2} \mathrm{~h}^{-1}$. Where available, errors show \pm 1 standard deviation.

\begin{tabular}{lllllll}
\hline Location & Season & Method & Isoprene & $\Sigma$ Monoterpene & Ratio & Reference \\
\hline Borneo, SE Asia & L Wet & vDEC & $0.48 \pm 0.72$ & $0.13 \pm 0.19$ & 0.27 & Langford et al., this study \\
Borneo, SE Asia & E Dry & vDEC & $1.04 \pm 1.3$ & $0.25 \pm 0.33$ & 0.24 & Langford et al., this study \\
Malaysia, SE Asia & Dry & LL & 1.1 & - & - & Saito et al. (2008) \\
Amazon, Brazil & E Dry & MB & 2.7 & 0.24 & 0.23 & Zimmerman et al. (1998) \\
Amazon, Peru & E Dry & MLG & 7.2 & 0.45 & 0.06 & Helmig et al. (1998) \\
Amazon, Brazil & L Wet & EC, REA & 2.1 & 0.23 & 0.11 & Rinne et al. (2002) \\
Amazon, Brazil & L Dry & vDEC & $7.3 \pm 2.7$ & $1.5 \pm 1.1$ & 0.21 & Karl et al. (2007) \\
Amazon, Brazil & L Dry & MLG & $10.2 \pm 3.5$ & $2.2 \pm 0.7$ & 0.22 & Karl et al. (2007) \\
Amazon, Brazil & L Dry & MLV & $11.0 \pm 0.9$ & $3.9 \pm 1.1$ & 0.35 & Karl et al. (2007) \\
Amazon, Brazil & E Dry & REA & $2.1 \pm 1.6$ & $0.39 \pm 0.43$ & 0.19 & Kuhn et al. (2007) \\
Amazon, Brazil & E Dry & SLG & $3.4 \pm 3.6$ & $0.38 \pm 0.58$ & 0.11 & Kuhn et al. (2007) \\
Amazon, Brazil & - & REA & 1.1 & 0.2 & 0.18 & Stefani et al. (2000) \\
Amazon, Brazil & - & BM & 1.9 & 0.16 & 0.08 & Greenberg et al. (2004) \\
Amazon, Brazil & - & BM & 4.7 & 0.20 & 0.04 & Greenberg et al. (2004) \\
Amazon, Brazil & - & BM & 8.6 & 0.54 & 0.06 & Greenberg et al. (2004) \\
Amazon, Brazil & Dry & EC & $0.4-1.5$ & - & - & Müller et al. (2008) \\
Amazon, Brazil & Wet & EC & $0.1-0.3$ & - & - & Müller et al. (2008) \\
French Guyana, & Dry & CBL & 6.1 & - & - & Eerdekens et al. (2009) \\
Suriname & & & & & & \\
Costa Rica & Wet & REA & 2.2 & - & - & Geron et al. (2002) \\
Costa Rica & Dry & DEC & 2.2 & 0.29 & 0.13 & Karl et al. (2004) \\
Congo, Africa & - & A-REA & 0.9 & - & - & Greenberg et al. (1999) \\
Congo, Africa & - & LL & $0.8-1$ & - & - & Klinger et al. (1998) \\
Congo, Africa & - & REA & $0.46-1.4$ & - & - & Serca et al. (2001) \\
\hline
\end{tabular}

EC = Eddy covariance; vDEC = Virtual disjunct eddy covariance; DEC = Disjunct eddy covariance; $(\mathrm{A})$-REA = $($ Airborne $)$ Relaxed eddy accumulation; SLG = Surface layer gradient; $\mathrm{MB}=$ Mass Budget; $\mathrm{MLG}=$ Mixed layer gradient; $\mathrm{MLV}=$ Mixed layer variance; $\mathrm{LL}=$ leaf level extrapolation; $\mathrm{BM}$ box $=$ modelling; $\mathrm{CBL}=\mathrm{Convective} \mathrm{boundary} \mathrm{layer}$ budgeting.

between 2000 and 2008, based on field-work in and around the Danum Valley area in 2000 and 2004, and from Dipterocarp rainforest species growing in the Yunnan Province, China, in 2003 and 2005. The database emission factors were used with vegetation survey data for different sample plots in the forest around the GAW tower for biomass weighted emission extrapolations for the plots. Thus best bottom-up estimates of canopy emissions were obtained for different sample plots with values ranging from 0.9 to $2.3 \mathrm{mg} \mathrm{m}^{-2} \mathrm{~h}^{-1}$ for isoprene and from 0.2 to $1.0 \mathrm{mg} \mathrm{m}^{-2} \mathrm{~h}^{-1}$ for total monoterpenes (Owen et al., 2010), which were in agreement with our direct canopy-scale flux measurements.

Although the extrapolated leaf-level measurements are on average larger than the measured fluxes, they are still well within the range of emission rates observed between wind sectors. The close agreement between canopy-scale fluxes and leaf-level measurements suggests that, although the tree species composition of the flux footprint is spatially heterogeneous, up-scaling of leaf level measurements can still yield representative results for this area.
Table 3 summarises the isoprene and monoterpene fluxes measured during the OP3 campaigns relative to previous findings from Amazonia, Africa and South East Asia. Our measurements of isoprene compared very closely to leaflevel estimates made from a dipterocarp forest on mainland Malaysia (Saito et al., 2008) and to observations above regions of the Congo, but were at the extreme lower end of observations from Amazonia. In contrast, our measurements of total monoterpene fluxes are somewhat larger than those previously reported for other tropical forests.

\subsubsection{Comparison of isoprene and monoterpene fluxes with modelled fluxes}

Emissions of isoprene from the flux footprint were simulated using the leaf-level light and temperature algorithm from the G06 emission model of Guenther et al. (2006). In the original G06 algorithm the fitting coefficients (Eqs. 5-9 of Guenther et al., 2006) are based on observations reported from five independent studies (Monson et al., 1994; Sharkey et al., 1999; Geron et al., 2000; Hanson and Sharkey, 2001; Petron et al., 2001), all of which report measurements from temperate plant species. In light of this, the coefficients used 
Table 4. Summary of the coefficients used to drive the MEGAN model. Standard coefficients are based upon studies of temperate plant species, whereas fitted coefficients relate to the measured flux data obtained during OP3-III over a tropical rainforest.

\begin{tabular}{lcrrrr}
\hline & \multicolumn{3}{c}{ G06 Standard Coefficients } & \multicolumn{2}{c}{ G06 Fitted Coefficients } \\
\hline \multicolumn{2}{l}{ Coefficients } & Isoprene & $\Sigma$ Monoterpenes & Isoprene & $\Sigma$ Monoterpenes \\
\hline$C T_{1}$ & (Eq. 5) & 95 & 95 & 142 & 95 \\
$C T_{2}$ & (Eq. 5) & 230 & 230 & 232 & 230 \\
$p_{o}$ & (Eq. 7) & 200 & 200 & 200 & 200 \\
$T_{\max }$ & (Eq. 8) & 313 & 313 & 316.1 & 312.9 \\
$x^{1}$ & (Eq. 6) & 0.004 & 0.004 & 0.006 & 0.006 \\
$x^{2}$ & (Eq. 6) & 0.0005 & 0.0005 & 0.0004 & 0.00025 \\
$x^{3}$ & (Eq. 7) & 0.0468 & 0.0468 & 0.0702 & 0.0702 \\
$x^{4}$ & (Eq. 9) & 2.034 & 2.034 & 3.051 & 2.058 \\
$x^{5}$ & (Eq. 8) & 0.6 & 0.6 & 0.52 & 0.47 \\
BER & & 1.65 & 0.4 & 2.5 & 0.5 \\
& & & & & \\
$R^{2}$ & & 0.47 & 0.44 & 0.50 & 0.45 \\
$M$ & & 0.56 & 0.51 & 0.43 & 0.37 \\
\hline
\end{tabular}

in the G06 algorithm were optimised for the emissions data reported in this paper by minimising the normalised mean square error $(M)$ between observed and modelled data using a quasi-Newton Raphson iterative method (Microsoft Excel 2003, Microsoft Corporation, Redmond, WA, USA):

$M=\frac{\left(\overline{E_{0}-E_{p}}\right)^{2}}{\overline{E_{0}} \cdot \overline{E_{p}}}$

Here $E_{\mathrm{o}}$ is the observed emission, $E_{\mathrm{p}}$ is the predicted emission and over bars denote mean values. The performance of the model is rated by the $M$ score, which is a function of bias magnitude, bias variance and intensity of association (Guenther et al., 1993) and decreases with increasing model performance. In order to constrain the optimisation to environmentally realistic conditions, each coefficient was given a tolerance of $\pm 50 \%$, with the exception of the temperature maximum $\left(T_{\max }\right)$ which was restricted to $\pm 1 \%$ to avoid unrealistically high or low temperatures. Table 4 lists the standard coefficients presented by Guenther et al. (2006) and the new optimised coefficients based on the results of this study.

Model variables such as PAR and temperature (past and present) were supplied from the in situ measurements made at the GAW station. Before use, the ambient air temperature measurements were first converted to give the canopy leaf temperatures required by the model using the resistance analogy described by Nemitz et al. (2009). Leaf temperatures during the afternoon were up to $2{ }^{\circ} \mathrm{C}$ higher than air temperature. Base emission rates describing isoprene and monoterpene emissions under constant (standard) conditions of temperature and PAR were inferred from the measured fluxes as described above. Our analysis assumes, as do all previous such analyses, that the BER is constant throughout the day. However, there are indications that BER varies throughout the day and this finding is explored more fully elsewhere (Hewitt et al., 2010b). We therefore used the peak in the average diurnal cycle of BER measured at this site, which occured at around midday. Figure 8 shows the simulated fluxes of isoprene (panel a) and monoterpenes (panel b) relative to the observed emissions over a 10-day period (2-12 July 2008).

Model estimates using the standard coefficients compare reasonably well with measured values, confirming temperature and light to be the primary drivers of observed emissions. On occasion, peak fluxes do not agree temporally between measured and modelled values. On 9 and $11 \mathrm{July}$, measured VOC fluxes peak in the morning, 2-3 h earlier than the modelled output. This is most likely the result of venting of the nocturnal boundary layer, described in Sect. 3.2.1. On other days ( 8 and 10 July), the peaks match temporally but are underestimated by the model. As the measured fluxes are integrated across the whole flux footprint, which covers an area of several square kilometres (Helfter et al., 2010) emissions respond to fluctuations in light and temperature across that footprint, which are not fully captured by our point measurements of PAR and temperature. In addition, the tree species composition in the footprint around the tower is very variable. Lowering the point of flux measurement closer to the canopy and thus reducing the flux footprint might improve model performance and result in a closer fit to the data, as demonstrated by measurements above an oil palm plantation reported by Misztal et al. (2010a), but at the cost of spatial representativeness. It should be noted that diurnal variation in the BER could not explain this discrepancy, since we use the peak value in the average diurnal pattern of BER, which coincides with midday. If we used the BER at any other time of day the discrepancy would be further increased. 

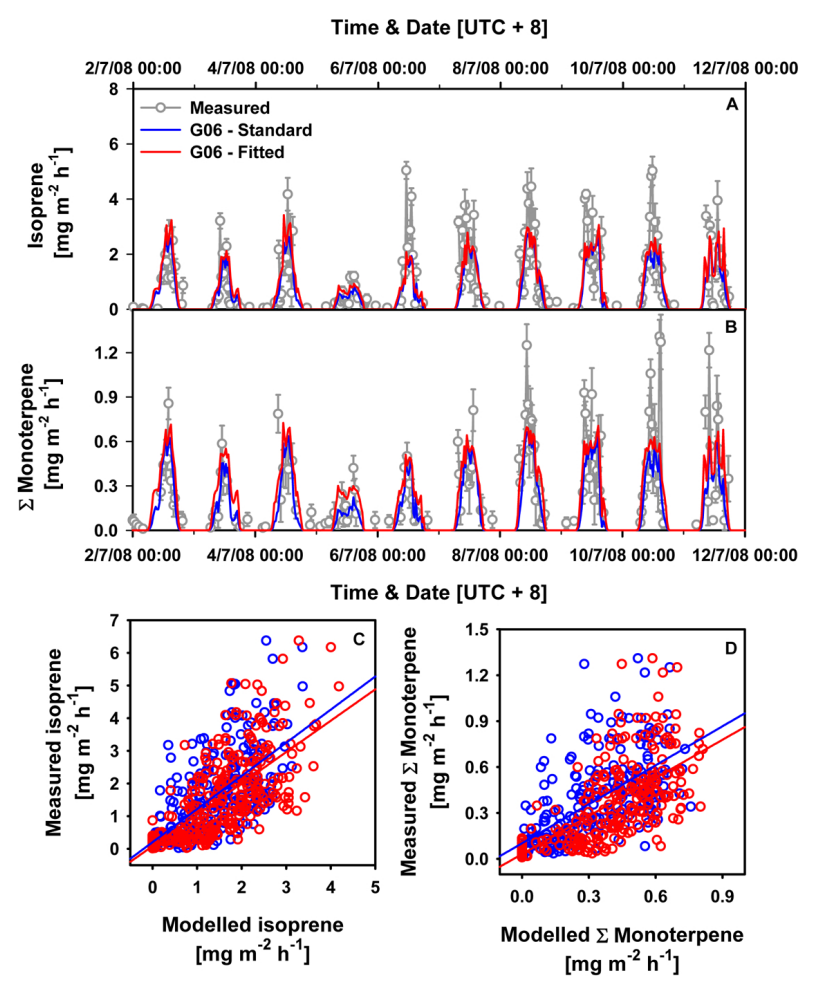

Fig. 8. Isoprene and monoterpene fluxes (grey line) measured by the virtual disjunct eddy covariance technique during the OP3-III field campaign. The blue line shows the model output when configured using the standard G06 coefficients and the red line shows the same output generated with empirically fitted parameters. Both sets of parameters, including basal emission rates normalised to $30^{\circ} \mathrm{C}$ and $1000 \mu \mathrm{mol} \mathrm{m}{ }^{-2} \mathrm{~s}^{-1}$ are listed in Table 3 .

Optimisation of the standard G06 coefficients resulted in new, site specific, light and temperature curves, which are shown in Fig. 9. For isoprene, the temperature response $\left(\gamma_{T}\right)$, shown in panel $\mathrm{A}$, doubles the normalised emission rates at peak values compared with the standard G06 response. The shape, higher $T_{\max }$ and increased emission rate of the fitted response is consistent with laboratory measurements of tropical plant species (Ficus virgata and Ficus microcarpa) made by Oku et al. (2008). In contrast, optimisation of the temperature response based on monoterpene fluxes showed no deviation from the standard G06 response. Panel B shows the light response $\left(\gamma_{\mathrm{P}}\right)$ of the fitted coefficients alongside the standard G06 light response. The fitted response of isoprene and monoterpenes are very similar, with emission rates following a steeper gradient at lower PAR values and saturating from $500 \mu \mathrm{mol} \mathrm{m}^{-2} \mathrm{~s}^{-1}$ of PAR onwards. This light response curve is very similar to those derived from laboratory measurements of oil palm (Wilkinson, 2006), a biofuel crop very common to the region, but not present within the GAW tower flux footprint, but differs significantly from sub-tropical tree species. For example, controlled environment measurements of isoprene emissions by Lerdau and Keller (1997) showed
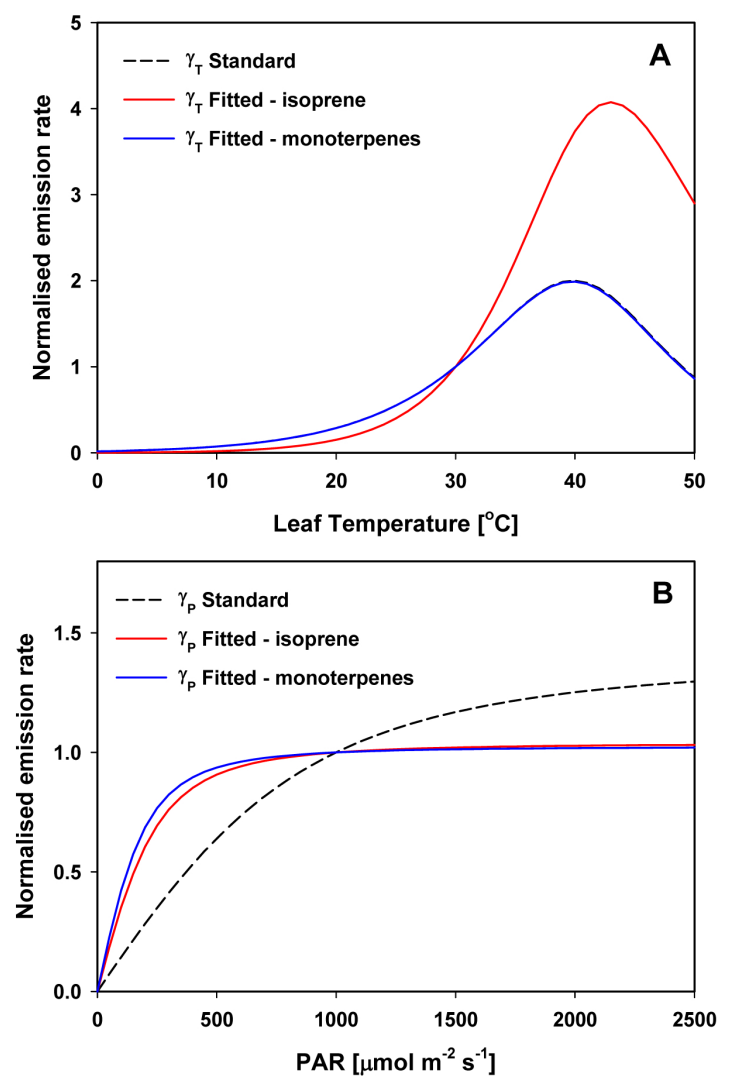

Fig. 9. The temperature (A) and light (B) response of the G06 algorithm. Dashed lines show the G06 response using standard coefficients which are based on temperate species only (in (A), the dashed line is directly below the blue line). Solid lines show the G06 response for isoprene (red) and monoterpenes (blue) using new coefficients which were obtained by fitting the algorithm response to measured fluxes above a tropical rainforest in Malaysian Borneo. In each response, past light and temperature values were set to: $\mathrm{T} 24=297, \mathrm{~T} 240=297$, PAR24=360, PAR $240=375$.

emission rates from sub-tropical tree species to increase with light intensity up to $2500 \mu \mathrm{mol} \mathrm{m}{ }^{-2} \mathrm{~s}^{-1}$ PAR. It should be noted that the optimised light and temperature curves presented here are for canopy-scale emissions and therefore they should only be applied to canopies with a similar structure.

Implementation of the optimised light and temperature response curves described above resulted in only a slight improvement in model performance, which suggests that the standard response curves of the G06 algorithm to perform adequately for both temperate and tropical vegetation, if the BER is adjusted. The BER appears to be the most important parameter, and failure to accurately characterise this can result in very large under- or over-estimations of canopy emission rates. For example, applying the default isoprene BER for tropical forests contained within MEGAN $\left(6.6 \mathrm{mg} \mathrm{m}^{-2} \mathrm{~h}^{-1}\right.$; value modified by the appropriate land cover type for the Danum valley region, see Hewitt et al. 
(2010a), Sect. 2.4), a parameter based on measurements made over the Amazonian rainforest, to regions of Borneo would result in a $>4$ times overestimation of the emission rate. Similarly, applying the default total monoterpene emission rate $\left(0.8 \mathrm{mg} \mathrm{m}^{-2} \mathrm{~h}^{-1}\right)$ would result in an overestimation of $>70 \%$.

In addition to the activities described above, which utilise the leaf-level light and temperature algorithms of MEGAN, isoprene and monoterpene fluxes were also simulated using the parameterised canopy environment emission algorithm (PCEEA), which is a simplified single-layer canopyscale representation of the multi-layer model. This version of MEGAN uses a modified set of algorithms to describe the canopy-scale isoprene emission response to light and temperature. These algorithms are based on simulations from the detailed MEGAN canopy environment (CE) model for warm, broad leafed forests and account for factors such as light and temperature attenuation through the canopy. The PCEEA model is intended to reduce the computational expense of running MEGAN in conjunction with a detailed CE model. When applied at the global-scale it can calculate isoprene emissions to within $5 \%$ of the full MEGAN model, but may exceed $25 \%$ when applied at specific locations and times (Guenther et al., 2006).

Our application of the PCEEA model gave a poorer fit with the observations for both standard $\left(R^{2}=0.42, M=0.62\right)$ and fitted coefficients $\left(R^{2}=0.43, M=0.52\right)$ when compared to using the standard leaf-level G06 algorithms. Importantly, the PCEEA model does not utilise information on the previous light and temperature conditions (24-240 h). Therefore, it appears that at this site, it is more important to include details of the previous environmental conditions than to include information on the structure of the canopy and its attenuation of light and temperature, at least if this is done in this simplified way. However, it should be noted that using a detailed canopy environment model may well result in an improved fit, yet the implementation and validation of such a model would go well beyond the scope of the current paper.

Our findings highlight the need for more direct canopyscale flux measurements of VOCs above the world's tropical forests to allow for further evaluation and constraint of models such as MEGAN.

\subsubsection{Fluxes of other BVOCs}

Fluxes of seven other BVOCs including methanol, acetone, acetaldehyde and acetic acid were measured during the two phases of the OP3 campaign; their average diurnal profiles are plotted alongside those of isoprene and monoterpenes in Fig. 10 with the results summarised in Table $2 b$. In addition to the canopy emissions of isoprene and monoterpenes discussed above, positive fluxes of acetaldehyde, acetone, hexanal and/or cis-3-hexenol, and EVK, were also observed. Average emission fluxes of acetaldehyde and acetone were of a similar magnitude and range, but emissions of ace- tone were larger during June and July relative to April and May, whereas acetaldehyde fluxes were slightly larger during April and May. Fluxes of hexanal and EVK were approximately half that of acetone and acetaldehyde, averaging $20 \mu \mathrm{g} \mathrm{m}^{-2} \mathrm{~h}^{-1}$, but mixing ratios of these two compounds were either very close to or below the limit of detection and therefore the fluxes of these compounds are not discussed further.

Previous studies over tropical forests have shown the bidirectional exchange of organic acids between canopy and atmosphere (Kuhn et al., 2002; Karl et al., 2004). Our measurements are consistent with these findings, with deposition fluxes observed for acetic acid during morning and early afternoon as well as small emission fluxes at certain times. Deposition velocities were in the range of $1-3 \mathrm{~mm} \mathrm{~s}^{-1}$, which is similar to those reported over the Amazonian rainforest by Kuhn et al. (2002) during the wet season. Correlations between instantaneous measurements of fluxes and ambient mixing ratios did not clearly show a compensation point as has been previously reported in leaf-level studies. However, it is likely that other sinks exist in the canopy (such as adsorption to leaf surfaces), which would affect the relationship between fluxes and concentrations. These findings should be treated with some caution as measurements of acetic acid by PTR-MS can be affected by memory effects in the inlet system and drift tube (de Gouw and Warneke, 2007).

Canopy profile measurements of methanol mixing ratios made by Ryder et al. (2010) showed elevated values close to the forest floor and their modelling of source/sink distributions indicates the forest floor to act as a source for methanol at certain times. Previous studies have shown methanol to be emitted during the decomposition of leaf material (Fall, 2003). However, our canopy scale flux measurements showed periods of both emission and deposition, with small net deposition. Previous studies in Amazonia have also shown both positive and negative fluxes of methanol, but the net exchange has always been reported as positive (Karl et al., 2004). The net deposition of methanol at this site, combined with its small deposition velocity, suggests that photo-oxidation is its primary source and results from the CiTTyCAT chemistry box model model indicate a methanol formation rate above the forest canopy of $1.7 \times 10^{5}$ molecules $\mathrm{cm}^{-3} \mathrm{~s}^{-1}$, equivalent to about $0.6 \mathrm{ppbv} \mathrm{day}^{-1}$.

The net exchange of MACR+MVK was negligible, with both positive and negative fluxes observed during each campaign. Positive fluxes were more common in the morning, whereas negative fluxes tended to be observed in the afternoon. This flux pattern may relate to the interplay between chemical sources/sinks and boundary layer dynamics. The net flux is the balance between the chemical production above and below the measurement height. During the first half of the day the boundary layer is shallower and most of the chemical formation happens below the measurement height, while in the afternoon most of the formation occurs above the canopy. 

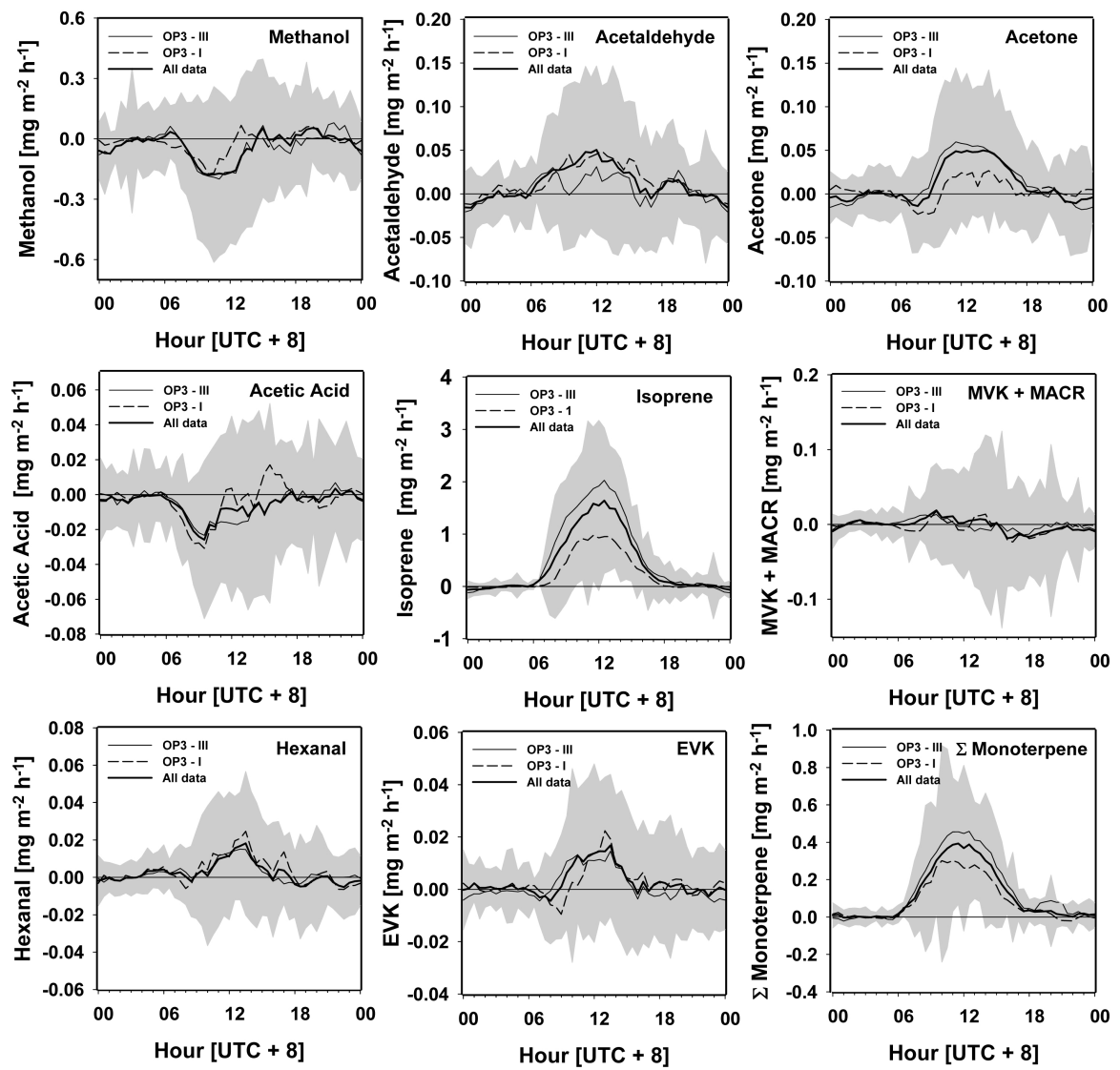

Fig. 10. Average diurnal profiles of VOC fluxes measured during the two intensive OP3 field campaigns which took place between 20 April7 May (OP3-I) and 20 June and 20 July (OP3-III), 2008. Greyed bands show \pm 1 standard deviation of averaged hourly values.

\subsection{Net ecosystem exchange of carbon}

Tropical forests assimilate carbon during the daytime and studies have shown that they currently act as a net carbon sink (Grace and Rayment, 2000). However, the carbon assimilated during the daytime is offset somewhat by the emission of VOCs from both the forest canopy and forest floor. We estimated this daytime offset by analysing total VOC emissions (all VOC measured during OP3; see Table $2 b$ for list) with respect to concurrently measured $\mathrm{CO}_{2}$ fluxes obtained during the OP3-III campaign (20 June-20 July 2008). Figure 11 shows the average diurnal profile of $\mathrm{CO}_{2}$ fluxes and total VOC exchange occurring above the forest canopy. Integrated $\mathrm{CO}_{2}$ fluxes yield a daytime (08:00-18:00) net carbon sink strength of $3120 \mathrm{mg} \mathrm{C} \mathrm{m}^{-2} \mathrm{~d}^{-1}$. Total VOC emissions, which had an integrated flux of $13.2 \mathrm{mg} \mathrm{C} \mathrm{m}^{-2} \mathrm{~d}^{-1}$ represented $0.4 \%$ of this (as carbon). The carbon offset from VOC fluxes above this SE Asian rainforest is lower than values reported above an Amazonian forest (1.2-3.7 \%; Kuhn et al., 2007; Karl et al., 2004), but this may be attributable to the limitations of the measurement system, which was decoupled from the canopy at night (see above) and unable to resolve nocturnal $\mathrm{CO}_{2}$ emissions due to respiration. Conse- quently our estimates of net ecosystem exchange (NEE) are for daytime only and guaranteed to be an overestimate. For a more detailed discussion of $\mathrm{CO}_{2}$ fluxes recorded during this campaign see Siong et al. (2010).

VOC emissions represent a loss of reactive carbon from the canopy, which after emission, will be photochemically processed and some of this carbon may therefore be deposited back to the canopy and hence the amount of carbon escaping the ecosystem is less than the measured VOC flux. For completness of carbon accounting, we ran the CiTTyCAT box model of atmospheric chemistry (Wild et al., 1996; Evans et al., 2000; Donovan et al., 2005; Hewitt et al., 2009; Pugh et al., 2010), including detailed isoprene chemistry (Taraborrelli et al., 2009), in the boundary layer above the flux footprint, to trace the fate of carbon emitted as VOCs. The model also includes detailed monoterpene chemistry (Jenkin, 1996; Stockwell et al., 1997), however the lumping of species within these schemes leads to a carbon loss of around $10 \%$ in the model. Therefore monoterpene emissions were neglected in these calculations to conserve carbon. For details on the CiTTyCAT model set-up see Pugh et al. (2010). 


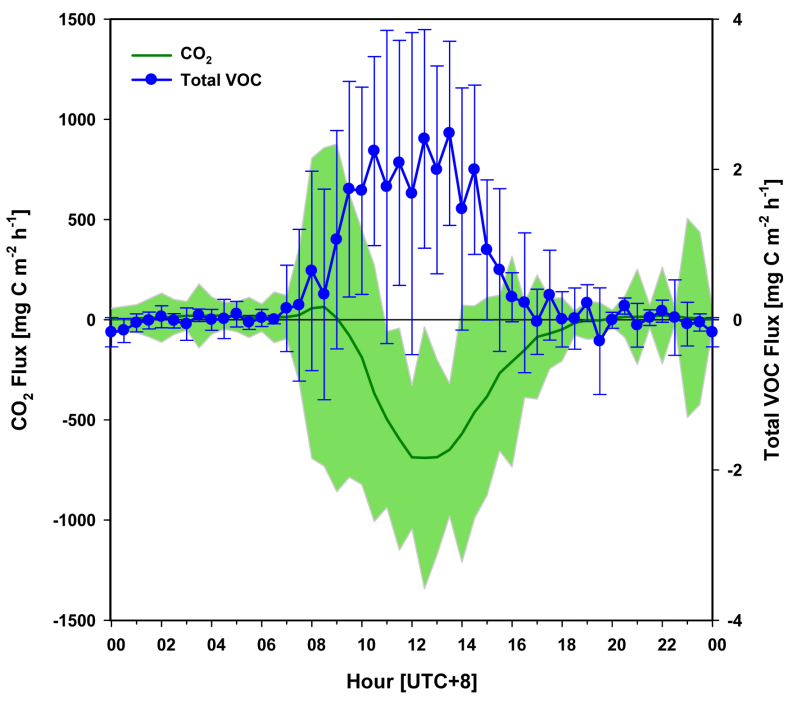

Fig. 11. Averaged diurnal profiles of $\mathrm{CO}_{2}$ and total VOC (sum of isoprene, monoterpenes, methanol, acetaldehyde, acetone, acetic acid, MVK+MACR, hexanal and EVK fluxes) fluxes measured above a SE Asian tropical rainforest during the period of 20 June20 July 2008. During the night time the measurements were decoupled from the forest canopy and therefore data shown during that period are not representative of the exchange occuring at the canopy top. Error bars and green bands show \pm 1 standard deviation of mean averaged values.

Isoprene was emitted following the diurnal cycle defined by the MEGAN algorithm (Guenther et al., 2006). The $24 \mathrm{~h}$ average emission rate was $6.88 \times 10^{10}$ molecules $\mathrm{cm}^{-2} \mathrm{~s}^{-1}$ $\left(0.28 \mathrm{mg} \mathrm{m}^{-2} \mathrm{~h}^{-1}\right)$. The only other emitted species was $\mathrm{NO}$, at a constant rate of $6.53 \times 10^{9}$ molecules $\mathrm{cm}^{-2} \mathrm{~s}^{-1}$ $\left(5.5 \mu \mathrm{g} \mathrm{m}^{-2} \mathrm{~h}^{-1}\right)$. A deposition velocity of $1.5 \mathrm{~cm} \mathrm{~s}^{-1}$ for MACR and MVK was adopted, following the findings of Pugh et al. (2010). Wet deposition (after Real et al., 2008, S-WET2 scheme) was also employed. The model does not include the formation of secondary organic aerosol, however the yields for isoprene are only a few percent (Hallquist et al., 2009). A carbon budget was calculated over the final four days of an eight-day model run, tracing the ultimate destination of the carbon emitted as isoprene. The model run indicated that the bulk of the reactive carbon emitted from the canopy is rapidly returned to the canopy in the near vicinity of the point of emission through both wet $(60 \%)$ and dry $(27 \%)$ deposition processes. A small fraction $(<4 \%)$ of the aldehydes, acids, nitrates and peroxides formed through photochemical reactions persist to be either further oxidised or deposited on a longer timescale, but only $9 \%(0.04 \%$ of daytime NEE) of the emitted reactive carbon escapes the landscape in the form of $\mathrm{CO}_{2}$. This fraction is somewhat lower than the global average, which is thought to range between 23-55\% (Goldstein and Galbally, 2007) and can be explained by the higher rates of wet and dry deposition found in the tropics.

\section{Summary and conclusions}

Direct canopy-scale measurements of VOC fluxes above a SE Asian tropical rainforest showed that isoprene was the dominant compound emitted, accounting for $80 \%$ (as carbon) of the total measured reactive carbon fluxes. Typical daytime fluxes ranged between 0.2 and $4.4 \mathrm{mg} \mathrm{m}^{-2} \mathrm{~h}^{-1}$ (10:00-14:00; 5th and 95th percentiles), which, when normalised to standard conditions $\left(30^{\circ} \mathrm{C} ; 1000 \mu \mathrm{mol} \mathrm{m}^{-2} \mathrm{~s}^{-1}\right.$ PAR), gave an average base emission rate of $1.6 \mathrm{mg} \mathrm{m}^{-2} \mathrm{~h}^{-1}$. This value was found to be 4.1 times smaller than the default standard emission rate used in the MEGAN model for tropical forests. With the exception of BER, optimisation of the empirical coefficients describing the temperature and PAR response used within MEGAN did not significantly improve the fit between measured and modelled data, lending confidence to the global application of these coefficients.

Total monoterpenes accounted for $18 \%$ of the reactive carbon fluxes, ranging between -0.1 and $1.0 \mathrm{mg} \mathrm{m}^{-2} \mathrm{~h}^{-1}$ (10:00-14:00; 5th and 95th percentiles) with an average base emission rate of $0.46 \mathrm{mg} \mathrm{m}^{-2} \mathrm{~h}^{-1}$. This value was $70 \%$ lower than the standard emission rate for monoterpenes used in the MEGAN model for tropical forests. Combined with the evidence from in-canopy measurements, these data demonstrate that monoterpenes were not emitted at night and during the day they were found to be dependent on both light and temperature.

The fluxes of other VOCs including the OVOCs, methanol, acetaldehyde and acetone, accounted for $<2 \%$ of the total reactive carbon flux. In total, the sum of the measured reactive carbon fluxes offset the daytime daytime assimilated carbon of the forest canopy by $0.4 \%$, but atmospheric box modelling suggests that most $(90 \%)$ of this reactive carbon is returned back to the canopy by wet and dry deposition following chemical transformation.

Acknowledgements. BL sincerely thanks Liew Boon Seng and all those who cared for him at the Sabah Medical Centre. The OP3 project was funded by the UK Natural Environment Research Council (NE/D002117/1). We thank the Malaysian and Sabah Governments for their permission to conduct research in Malaysia; the Malaysian Meteorological Department for access to the Bukit Atur Global Atmosphere Watch station; Waidi Sinun of Yayasan Sabah and Glen Reynolds of the Royal Society's South East Asian Rain Forest Research Programme for logistical support at the Danum Valley Research Station and the Royal Society research assistants Alexander Karolus, Johnny Larenus and Hadam Taman for logistical support; Malcolm Possell, Annette Ryan, Kirsti Ashworth and Sue Owen for helpful discussion and the entire OP3 team for their individual and combined efforts. In particular, we acknowledge Gavin Phillips, Chiara Di Marco and Mhairi Coyle for help with the instrument setup on the GAW tower. This is paper 506 of the Royal Society's South-East Asian Rainforest Research Programme.

Edited by: A. B. Guenther 


\section{References}

Ammann, C., Brunner, A., Spirig, C., and Neftel, A.: Technical note: Water vapour concentration and flux measurements with PTR-MS, Atmos. Chem. Phys., 6, 4643-4651, doi:10.5194/acp6-4643-2006, 2006.

Barkley, M. P., Palmer, P. I., De Smedt, I., Karl, T., Guenther, A., and Van Roozendael, M.: Regulated large-scale annual shutdown of Amazonian isoprene emissions?, Geophys. Res. Lett., 36, L04803, doi:10.1029/2008GL036843, 2009.

Claeys, M., Graham, B., Vas, G., Wang, W., Vermeylen, R., Pashynska, V., Cafmeyer, J., Guyon, P., Andreae, M. O., Artaxo, P., and Maenhaut, W.: Formation of secondary organic aerosols through photooxidation of isoprene, Science, 303, 1173-1176, 2004.

Davison, B., Taipale, R., Langford, B., Misztal, P., Fares, S., Matteucci, G., Loreto, F., Cape, J. N., Rinne, J., and Hewitt, C. $\mathrm{N}$.: Concentrations and fluxes of biogenic volatile organic compounds above a Mediterranean macchia ecosystem in western Italy, Biogeosciences, 6, 1655-1670, doi:10.5194/bg-6-16552009, 2009.

de Gouw, J. and Warneke, C.: Measurements of volatile organic compounds in the earths atmosphere using proton-transferreaction mass spectrometry, Mass Spectrom. Rev., 26, 223-257, 2007.

Donovan, R. G., Hope, E. S., Owen, S. M., Mackenzie, A. R., and Hewitt, C. N.: Development and Application of an Urban Tree Air Quality Score for Photochemical Pollution Episodes Using the Birmingham, United Kingdom, Area as a Case Study, Environ. Sci. Technol., 39, 6730-6738, 2005.

Eerdekens, G., Ganzeveld, L., Vilà-Guerau de Arellano, J., Klüpfel, T., Sinha, V., Yassaa, N., Williams, J., Harder, H., Kubistin, D., Martinez, M., and Lelieveld, J.: Flux estimates of isoprene, methanol and acetone from airborne PTR-MS measurements over the tropical rainforest during the GABRIEL 2005 campaign, Atmos. Chem. Phys., 9, 4207-4227, doi:10.5194/acp-9-42072009, 2009.

Evans, M. J., Shallcross, D. E., Law, K. S., Wild, J. O. F., Simmonds, P. G., Spain, T. G., Berrisford, P., Methven, J., Lewis, A. C., McQuaid, J. B., Pilling, M. J., Bandy, B. J., Penkett, S. A., and Pyle, J. A.: Evaluation of a Langrangian box model using field measurements from EASE (Eastern Atlantic Summer Experiment) 1996, Atmos. Environ., 34, 3843-3863, 2000.

Fall, R.: Abundent oxygenates in the atmosphere: A biochemical perspective, Chem. Rev., 103(12), 4941-4952, 2003.

Foken, T., Gckede, M., Mauder, M., Mahrt, L., Amiro, B., and Munger. W.: Post-field data quality control, in: Handbook of Micrometeorology: A guide for surface flux measurement and analysis, edited by: Lee, W. M. X. and Law, B., Dordrecht, Kluer Academic Publishers, 29, 181-203, 2004.

Fowler, D.: Ground-level ozone in the 21 st century: future trends, impacts and policy implications, Royal Society, London, UK, 2008.

Geron, C., Guenther, A., Sharkey, T., and Arnts, R. R.: Temporal variability in basal isoprene emission factor, Tree Physiology, 20, 799-805, 2000.

Geron, C., Guenther, A., Greenberg, J., Loescher, H. W., Clark, D., and Baker, B.: Biogenic volatile organic compound emissions from a lowland tropical wet forest in costa rica, Atmos. Environ., 36, 3793-3802, 2002.

Goldstein, A. H. and Galbally, I. E.: Known and unexplored organic constituents in the earth's atmosphere, Environ. Sci. Technol., 41, 1514-1521, 2007.

Grace, J. and Rayment, M.: Respiration in the balance, Nature, 404, 819-820, doi:10.1038/35009170, 2000.

Granier, C., Petron, G., Muller, J. F., and Brasseur, G.: The impact of natural and anthropogenic hydrocarbons on the tropospheric budget of carbon monoxide, Atmos. Environ., 34, 5255-5270, 2000.

Greenberg, J. P., Guenther, A. B., Madronich, S., Baugh, W., Ginoux, P., Druilhet, A., Delmas, R., and Delon, C.: Biogenic volatile organic compound emissions in central Africa during the experiment for the regional sources and sinks of oxidants (EXPRESSO) biomass burning season, J. Geophys. Res.-Atmos., 104, 30659-30671, 1999.

Greenberg, J. P., Guenther, A. B., Petron, G., Wiedinmyer, C., Vega, O., Gatti, L. V., Tota, J., and Fisch, G.: Biogenic voc emissions from forested amazonian landscapes, Global Change Biol., 10, 651-662, 2004.

Guenther, A.: Seasonal and spatial variations in natural volatile organic compound emissions, Ecol. Appl., 7, 34-45, 1997.

Guenther, A., Karl, T., Harley, P., Wiedinmyer, C., Palmer, P. I., and Geron, C.: Estimates of global terrestrial isoprene emissions using MEGAN (Model of Emissions of Gases and Aerosols from Nature), Atmos. Chem. Phys., 6, 3181-3210, doi:10.5194/acp-63181-2006, 2006.

Guenther, A. B., Zimmerman, P. R., Harley, P. C., Monson, R. K., and Fall, R.: Isoprene and monoterpene emission rate variability - model evaluations and sensitivity analyses, J. Geophys. Res.Atmos., 98, 12609-12617, 1993.

Guenther, A., Hewitt, C. N., Karl, T., Harley, P., and Reeves, C.: Biogenic VOC emissions from African, American and Asian tropical rainforests, Eos Trans. AGU, 89(53), Fall Meet. Suppl., Abstract A14C-04, 2008.

Hallquist, M., Wenger, J. C., Baltensperger, U., Rudich, Y., Simpson, D., Claeys, M., Dommen, J., Donahue, N. M., George, C., Goldstein, A. H., Hamilton, J. F., Herrmann, H., Hoffmann, T., Iinuma, Y., Jang, M., Jenkin, M. E., Jimenez, J. L., Kiendler-Scharr, A., Maenhaut, W., McFiggans, G., Mentel, Th. F., Monod, A., Prévôt, A. S. H., Seinfeld, J. H., Surratt, J. D., Szmigielski, R., and Wildt, J.: The formation, properties and impact of secondary organic aerosol: current and emerging issues, Atmos. Chem. Phys., 9, 5155-5236, doi:10.5194/acp-95155-2009, 2009.

Hanson, D. T. and Sharkey, T. D.: Rate of acclimation of the capacity for isoprene emission in response to light and temperature, Plant Cell Environ., 24, 937-946, 2001.

Hayward, S., Hewitt, C. N., Sartin, J. H., and Owen, S. M.: Performance characteristics and applications of a proton transfer reaction-mass spectrometer for measuring volatile organic compounds in ambient air, Environ. Sci. Technol., 36, 1554-1560, 2002.

Helfter, C., Phillips, G. J., Coyle, M., Di Marco, C. F., Langford, B., Whitehead, J., Dorsey, J. R., Gallagher, M. W., Sei, E. Y., Fowler, D., and Nemitz, E.: Momentum and heat exchange above South East Asian rainforest in complex terrain, Atmos. Chem. Phys. Discuss., in preparation, 2010.

Helmig, D., Balsley, B., Davis, K., Kuck, L. R., Jensen, M., Bognar, J., Smith, T., Arrieta, R. V., Rodriguez, R., and Birks, J. W.: Vertical profiling and determination of landscape fluxes of bio- 
genic nonmethane hydrocarbons within the planetary boundary layer in the Peruvian Amazon, J. Geophys. Res.-Atmos., 103, 25519-25532, 1998 .

Hewitt, C. N., Hayward, S., and Tani, A.: The application of proton transfer reaction-mass spectrometry (ptr-ms) to the monitoring and analysis of volatile organic compounds in the atmosphere, J. Environ. Monitoring, 5, 1-7, 2003.

Hewitt, C. N., MacKenzie, A. R., Di Carlo, P., Di Marco, C. F., Dorsey, J. R., Evans, M., Fowler, D., Gallagher, M. W., Hopkins, J. R., Jones, C. E., Langford, B., Lee, J. D., Lewis, A. C., Lim, S. F., McQuaid, J., Misztal, P., Moller, S. J., Monks, P. S., Nemitz, E., Oram, D. E., Owen, S. M., Phillips, G. J., Pugh, T. A. M., Pyle, J. A., Reeves, C. E., Ryder, J., Siong, J., Skiba, U., and Stewart, D. J.: Nitrogen management is essential to prevent tropical oil palm plantations from causing ground-level ozone pollution, P. Natl. Acad. Sci. USA, 106, 18447-18451, 2009.

Hewitt, C. N., Lee, J. D., MacKenzie, A. R., Barkley, M. P., Carslaw, N., Carver, G. D., Chappell, N. A., Coe, H., Collier, C., Commane, R., Davies, F., Davison, B., DiCarlo, P., Di Marco, C. F., Dorsey, J. R., Edwards, P. M., Evans, M. J., Fowler, D., Furneaux, K. L., Gallagher, M., Guenther, A., Heard, D. E., Helfter, C., Hopkins, J., Ingham, T., Irwin, M., Jones, C., Karunaharan, A., Langford, B., Lewis, A. C., Lim, S. F., MacDonald, S. M., Mahajan, A. S., Malpass, S., McFiggans, G., Mills, G., Misztal, P., Moller, S., Monks, P. S., Nemitz, E., Nicolas-Perea, V., Oetjen, H., Oram, D. E., Palmer, P. I., Phillips, G. J., Pike, R., Plane, J. M. C., Pugh, T., Pyle, J. A., Reeves, C. E., Robinson, N. H., Stewart, D., Stone, D., Whalley, L. K., and Yin, X.: Overview: oxidant and particle photochemical processes above a south-east Asian tropical rainforest (the OP3 project): introduction, rationale, location characteristics and tools, Atmos. Chem. Phys., 10, 169-199, doi:10.5194/acp-10169-2010, 2010a.

Hewitt, C. N., Ashworth, K., Langford, B., MacKenzie, A. R., Misztal, P. K., Nemitz, E., Owen, S. M., Possell, M., Pugh, T. A. M., Ryan, A. C., and Wild, O.: Circadian control reduces isoprene emissions from forests and moderates ground-level ozone, in preparation, $2010 \mathrm{~b}$.

Horst, T. W.: A simple formula for attenuation of eddy fluxes measured with first-order-response scalar sensors, Bound.-Lay. Meteor., 82, 219-233, 1997.

Jenkin, M. E.: Chemical Mechanisms forming condensable material. AEA Technology Report, AEA/RAMP/20010010/002, 1996.

Jones, C. E., Hopkins, J. R., Langford, B., and Lewis, A. C.: Measurements of isoprene and speciated monoterpenes by GCFID within a south-east Asian tropical rainforest, Atmos. Chem. Phys. Discuss., in preparation, 2010.

Karl, T. G., Spirig, C., Rinne, J., Stroud, C., Prevost, P., Greenberg, J., Fall, R., and Guenther, A.: Virtual disjunct eddy covariance measurements of organic compound fluxes from a subalpine forest using proton transfer reaction mass spectrometry, Atmos. Chem. Phys., 2, 279-291, doi:10.5194/acp-2-279-2002, 2002.

Karl, T., Hansel, A., Mark, T., Lindinger, W., and Hoffmann, D.: Trace gas monitoring at the Mauna Loa baseline observatory using proton transfer reaction mass spectrometry, Int. J. Mass Spectrom., 223-224, 527-538, 2003.

Karl, T., Potosnak, M., Guenther, A., Clark, D., Walker, J., Herrick, J. D., and Geron, C.: Exchange processes of volatile organic compounds above a tropical rain forest: Implications for modeling tropospheric chemistry above dense vegetation, J. Geophys. Res.-Atmos., 109, D18306, doi:10.1029/2004JD004738, 2004.

Karl, T., Guenther, A., Yokelson, R. J., Greenberg, J., Potosnak, M., Blake, D. R., and Artaxo, P.: The tropical forest and fire emissions experiment: Emission, chemistry, and transport of biogenic volatile organic compounds in the lower atmosphere over Amazonia, J. Geophys. Res.-Atmos., 112, D18302, doi:10.1029/2007JD008539, 2007.

Karl, T., Guenther, A., Turnipseed, A., Tyndall, G., Artaxo, P., and Martin, S.: Rapid formation of isoprene photo-oxidation products observed in Amazonia, Atmos. Chem. Phys., 9, 7753-7767, doi:10.5194/acp-9-7753-2009, 2009.

Kesselmeier, J., Kuhn, U., Rottenberger, S., Biesenthal, T., Wolf, A., Schebeske, G., Andreae, M. O., Ciccioli, P., Brancaleoni, E., Frattoni, M., Oliva, S. T., Botelho, M. L., Silva, C. M. A., and Tavares, T. M.: Concentrations and species composition of atmospheric volatile organic compounds (VOCs) as observed during the wet and dry season in Rondonia (Amazonia), J. Geophys. Res.-Atmos., 107(D20), 8053, doi:10.1029/2000JD000267, 2002.

Khare, P., Kumar, N., Kumari, K. M., and Srivastava, S. S.: Atmospheric formic and acetic acids: An overview, Rev. Geophys., 37(2), 227-248, 1999.

Kiendler-Scharr, A., Wildt, J., Dal Maso, M., Hohaus, T., Kleist, E., Mentel, T. F., Tillmann, R., Uerlings, R., Schurr, U., and Wahner, A.: New particle formation in forests inhibited by isoprene emissions, Nature, 461, 381-384, 2009.

Kleindienst, T. E., Edney, E. O., Lewandowski, M., Offenberg, J. H., and Jaoui, M.: Secondary organic carbon and aerosol yields from the irradiations of isoprene and alpha-pinene in the presence of $\mathrm{NO}_{\mathrm{x}}$ and $\mathrm{SO}_{2}$, Environ. Sci. Technol., 40, 3807-3812, 2006.

Klinger, L. F., Greenberg, J., Guenther, A., Tyndall, G., Zimmerman, P., M'Bangui, M., and Moutsambote, J. M.: Patterns in volatile organic compound emissions along a savanna-rainforest gradient in central Africa, J. Geophys. Res.-Atmos., 103, 14431454, 1998.

Kroll, J. H., Ng, N. L., Murphy, S. M., Flagan, R. C., and Seinfeld, J. H.: Secondary organic aerosol formation from isoprene photooxidation under high-NOx conditions, Geophys. Res. Lett., 32, L18808, doi:10.1029/2005GL023637, 2005.

Kroll, J. H., Ng, N. L., Murphy, S. M., Flagan, R. C., and Seinfeld, J. H.: Secondary organic aerosol formation from isoprene photooxidation, Environ. Sci. Technol., 40, 1869-1877, 2006.

Kuhn, U., Rottenberger, S., Biesenthal, T., Ammann, C., Wolf, A., Schebeske, G., Oliva, S. T., Tavares, T. M., and Kesselmeier, J.: Exchange of short-chain monocarboxylic acids by vegetation at a remote tropical forest site in Amazonia, J. Geophys. Res.Atmos., 107, 8069, doi:10.1029/2002JD000303, 2002.

Kuhn, U., Andreae, M. O., Ammann, C., Araújo, A. C., Brancaleoni, E., Ciccioli, P., Dindorf, T., Frattoni, M., Gatti, L. V., Ganzeveld, L., Kruijt, B., Lelieveld, J., Lloyd, J., Meixner, F. X., Nobre, A. D., Pöschl, U., Spirig, C., Stefani, P., Thielmann, A., Valentini, R., and Kesselmeier, J.: Isoprene and monoterpene fluxes from Central Amazonian rainforest inferred from towerbased and airborne measurements, and implications on the atmospheric chemistry and the local carbon budget, Atmos. Chem. Phys., 7, 2855-2879, doi:10.5194/acp-7-2855-2007, 2007.

Langford, B., Davison, B., Nemitz, E., and Hewitt, C. N.: Mix- 
ing ratios and eddy covariance flux measurements of volatile organic compounds from an urban canopy (Manchester, UK), Atmos. Chem. Phys., 9, 1971-1987, doi:10.5194/acp-9-1971-2009, 2009.

Langford, B., Nemitz, E., House, E., Phillips, G. J., Famulari, D., Davison, B., Hopkins, J. R., Lewis, A. C., and Hewitt, C. N.: Fluxes and concentrations of volatile organic compounds above central London, UK, Atmos. Chem. Phys., 10, 627-645, doi:10.5194/acp-10-627-2010, 2010.

Laothawornkitkul, J., Taylor, J. E., Paul, N. D., and Hewitt, C. N.: Biogenic volatile organic compounds in the earth system, New Phytol., 183, 27-51, 2009.

Lee, J. D., Lewis, A. C., Monks, P. S., Jacob, M., Hamilton, J. F., Hopkins, J. R., Watson, N. M., Saxton, J. E., Ennis, C., Carpenter, L. J., Carslaw, N., Fleming, Z., Bandy, B. J., Oram, D. E., Penkett, S. A., Slemr, J., Norton, E., Rickard, A. R., Whalley, L. K., Heard, D. E., Bloss, W. J., Gravestock, T., Smith, S. C., Stanton, J., Pilling, M. J., and Jenkin, M. E.: Ozone photochemistry and elevated isoprene during the UK heat wave of August 2003, Atmos. Environ., 40, 7598-7613, 2006.

Lelieveld, J., Peters, W., Dentener, F. J., and Krol, M. C.: Stability of tropospheric hydroxyl chemistry, J. Geophys. Res.-Atmos., 107, 4715, doi:10.1029/2002JD002272, 2002.

Lerdau, M., and Keller, M.: Controls on isoprene emission from trees in a subtropical dry forest, Plant Cell Environ., 20, 569578, 1997.

Lewis, S. L., Lopez-Gonzalez, G., Sonke, B., Affum-Baffoe, K., Baker, T. R., Ojo, L. O., Phillips, O. L., Reitsma, J. M., White, L., Comiskey, J. A., Djuikouo, M. N., Ewango, C. E. N., Feldpausch, T. R., Hamilton, A. C., Gloor, M., Hart, T., Hladik, A., Lloyd, J., Lovett, J. C., Makana, J. R., Malhi, Y., Mbago, F. M., Ndangalasi, H. J., Peacock, J., Peh, K. S. H., Sheil, D., Sunderland, T., Swaine, M. D., Taplin, J., Taylor, D., Thomas, S. C., Votere, R., and Woll, H.: Increasing carbon storage in intact African tropical forests, Nature, 457, 1003-1003, 2009.

Lindinger, W., Hansel, A., and Jordan, A.: Proton-transfer-reaction mass spectrometry (PTR-MS): On-line monitoring of volatile organic compounds at pptv levels, Chem.1 Soc. Rev., 27, 347-354, 1998.

Martin, R. S., H. Westberg, E. Allwine, L. Ashman, J. C. Farmer, and B. Lamb.: Measurement of isoprene and its atmospheric oxidation products in a central Pennsylvania deciduous forest, J. Atmos. Chem., 13, 1-32, 1991.

Misztal, P. K., Nemitz, E., Langford, B., Coyle, M., Ryder, J., Di Marco, C., Phillips, G., Oram, D., Owen, S., and Cape, J. N.: First direct ecosystem fluxes of VOCs from oil palms in SE Asia. Atmos. Chem. Phys. Discuss, in preparation, 2010a.

Misztal, P. K., Owen, S. M., Guenther, A. B., Rasmussen, R., Geron, C., Harley, P., Phillips, G. J., Ryan, A., Edwards, D. P., Hewitt, C. N., Nemitz, E., Siong, J., Heal, M. R., and Cape, J. N.: Large estragole fluxes from oil palms in Borneo, Atmos. Chem. Phys., 10, 4343-4358, doi:10.5194/acp-10-4343-2010, $2010 \mathrm{~b}$.

Moncrieff, J., Finnigan, R. C. J., and Meyers, T.: Averaging, detrending, and filtering of eddy covariance time series, in: Handbook of Micrometeorology: A guide for surface flux measurement and analysis, edited by: Lee, W. M. X. and Law, B., Dordrecht, Kluer Academic Publishers, 29, 7-30, 2004.

Monson, R. K., Harley, P. C., Litvak, M. E., Wildermuth, M., Guenther, A. B., Zimmerman, P. R., and Fall, R.: Environmental and developmental controls over the seasonal pattern of isoprene emission from aspen leaves, Oecologia, 99, 260-270, 1994.

Müller, J.-F., Stavrakou, T., Wallens, S., De Smedt, I., Van Roozendael, M., Potosnak, M. J., Rinne, J., Munger, B., Goldstein, A., and Guenther, A. B.: Global isoprene emissions estimated using MEGAN, ECMWF analyses and a detailed canopy environment model, Atmos. Chem. Phys., 8, 1329-1341, doi:10.5194/acp-81329-2008, 2008.

Nemitz, E., Hargreaves, K. J., Neftel, A., Loubet, B., Cellier, P., Dorsey, J. R., Flynn, M., Hensen, A., Weidinger, T., Meszaros, R., Horvath, L., Dmmgen, U., Frühauf, C., Löpmeier, F. J., Gallagher, M. W., and Sutton, M. A.: Intercomparison and assessment of turbulent and physiological exchange parameters of grassland, Biogeosciences, 6, 1445-1466, doi:10.5194/bg-61445-2009, 2009.

Ng, N. L., Kwan, A. J., Surratt, J. D., Chan, A. W. H., Chhabra, P. S., Sorooshian, A., Pye, H. O. T., Crounse, J. D., Wennberg, P. O., Flagan, R. C., and Seinfeld, J. H.: Secondary organic aerosol (SOA) formation from reaction of isoprene with nitrate radicals $\left(\mathrm{NO}_{3}\right)$, Atmos. Chem. Phys., 8, 4117-4140, doi:10.5194/acp-84117-2008, 2008.

Oku, H., Fukuta, M., Iwasaki, H., Tambunan, P., and Baba, S.: Modification of the isoprene emission model G93 for tropical tree ficus virgata, Atmos. Environ., 42, 8747-8754, 2008.

Owen, S. M., Harley, P., Guenther, A., and Hewitt, C. N.: Light dependency of voc emissions from selected mediterranean plant species, Atmos. Environ., 36, 3147-3159, 2002.

Owen, S. M., Ryan, A., Linatoc, A., Geron, C., Harley, P., Rasmussen, R., Guenther, A., Wilkinson, M.J., Llusia, J., Penuelas, J., Yap, S. W., Sinun, W., and Hewitt C. N., Leaf level emissions of volatile organic compounds (VOCs) from tropical rainforest tree species in south east Asia, Atmos. Chem. Phys. Discuss, in preparation, 2010.

Paulot, F., Crounse, J. D., Kjaergaard, H. G., Kroll, J. H., Seinfeld, J. H., and Wennberg, P. O.: Isoprene photooxidation: new insights into the production of acids and organic nitrates, Atmos. Chem. Phys., 9, 1479-1501, doi:10.5194/acp-9-1479-2009, 2009.

Pearson, G., Davies, F., and Collier, C.: Remote sensing of the tropical rain forest boundary layer using pulsed Doppler lidar, Atmos. Chem. Phys., 10, 5891-5901, doi:10.5194/acp-10-58912010, 2010.

Petron, G., Harley, P., Greenberg, J., and Guenther, A.: Seasonal temperature variations influence isoprene emission, Geophys. Res. Lett., 28, 1707-1710, 2001.

Pitman, N. C. A., Terborgh, J., Silman, M. R., and Nuez, P.: Tree species distributions in an upper Amazonian forest, Ecology, 80, 2651-2661, 1999.

Pugh, T. A. M., MacKenzie, A. R., Hewitt, C. N., Langford, B., Edwards, P. M., Furneaux, K. L., Heard, D. E., Hopkins, J. R., Jones, C. E., Karunaharan, A., Lee, J., Mills, G., Misztal, P., Moller, S., Monks, P. S., and Whalley, L. K.: Simulating atmospheric composition over a South-East Asian tropical rainforest: performance of a chemistry box model, Atmos. Chem. Phys., 10, 279-298, doi:10.5194/acp-10-279-2010, 2010.

Real, E., Law, K. S., Schlager, H., Roiger, A., Huntrieser, H., Methven, J., Cain, M., Holloway, J., Neuman, J. A., Ryerson, T., Flocke, F., de Gouw, J., Atlas, E., Donnelly, S., and Parrish, D.: Lagrangian analysis of low altitude anthropogenic plume pro- 
cessing across the North Atlantic, Atmos. Chem. Phys., 8, 77377754, doi:10.5194/acp-8-7737-2008, 2008.

Rinne, H. J. I., Guenther, A. B., Greenberg, J. P., and Harley, P. C.: Isoprene and monoterpene fluxes measured above Amazonian rainforest and their dependence on light and temperature, Atmos. Environ., 36, 2421-2426, 2002.

Robinson, N., Hamilton, J. F., Allan, J. D., Langford, B., Oram, D. E., Chen, Q., Docherty, K., Farmer, D., Jimenez, J. L., Ward, M., Hewitt, C.N., Barley, M. H., Jenkin, M. E., Rickard, A. R., Martin, S. T., Coe, H., and McFiggans, G.: Evidence for a High Proportion of Biogenic Atmospheric Organic Aerosol from Isoprene, Atmos. Chem. Phys. Discuss., in preparation, 2010.

Ryder, J., Langford, B., Oram, D., Coyle, M., Phillips, G., Helfter, C., Misztal, P., Cape, N., and Nemitz, E.: Sources and sinks of BVOCs inside a SE Asian rainforest canopy, Atmos. Chem. Phys. Discuss., in preparation, 2010.

Saito, T., Yokouchi, Y., Kosugi, Y., Tani, M., Philip, E., and Okuda, T.: Methyl chloride and isoprene emissions from tropical rain forest in southeast Asia, Geophys. Res. Lett., 35, L19812, doi:10.1029/2008GL035241, 2008.

Serca, D., Guenther, A., Klinger, L., Vierling, L., Harley, P., Druilhet, A., Greenberg, J., Baker, B., Baugh, W., Bouka-Biona, C., and Loemba-Ndembi, J.: EXPRESSO flux measurements at upland and lowland Congo tropical forest site, Tellus B, 53, 220234, 2001.

Sharkey, T. D., Singsaas, E. L., Lerdau, M. T., and Geron, C. D.: Weather effects on isoprene emission capacity and applications in emissions algorithms, Ecol. Appl., 9, 1132-1137, 1999.

Sillman, S.: The relation between ozone, $\mathrm{NO}_{\mathrm{x}}$ and hydrocarbons in urban and polluted rural environments, Atmos. Environ., 33, 1821-1845, 1999.

Siong, J., Helfter, C., Di Marco, C. Linatoc, A., Nemitz, E., Fowler, D., and Skiba, U. M.: Greenhouse gas $\left(\mathrm{N}_{2} \mathrm{O}, \mathrm{CH}_{4}\right.$ and $\left.\mathrm{CO}_{2}\right)$ exchange with contrasting land uses in SE Asia, Atmos. Chem. Phys. Discuss., in preparation, 2010.

Spirig, C., Neftel, A., Ammann, C., Dommen, J., Grabmer, W., Thielmann, A., Schaub, A., Beauchamp, J., Wisthaler, A., and Hansel, A.: Eddy covariance flux measurements of biogenic VOCs during ECHO 2003 using proton transfer reaction mass spectrometry, Atmos. Chem. Phys., 5, 465-481, doi:10.5194/acp-5-465-2005, 2005.

Stefani, P., Valentini, R., Ciccioli, P., Brancaleoni, E., Frattoni, M., Nobre, A., and De Araujo, A.: Preliminary assessment of VOC fluxes from a primary rain forest performed at the LBA site in Manuas, in Proceedings of the First LBA Scientific Conference, edited by: Artaxo, P. and Keller, M., 106, MCT, Belem, Brazil, 2000 .
Steinbacher, M., Dommen, J., Ammann, C., Spirig, C., Neftel, A., and Prevot, A. S. H.: Performance characteristics of a protontransfer-reaction mass spectrometer (ptr-ms) derived from laboratory and field measurements, Int. J. Mass Spectrom., 239, 117128, 2004.

Stockwell, W. R., Kirchner, F., Kuhn, M., and Seefeld, S.: A new mechanism for regional atmospheric chemistry modeling, J. Geophys. Res., 102(D22), 25847-25879, 1997.

Taipale, R., Ruuskanen, T. M., Rinne, J., Kajos, M. K., Hakola, H., Pohja, T., and Kulmala, M.: Technical Note: Quantitative long-term measurements of VOC concentrations by PTR-MS measurement, calibration, and volume mixing ratio calculation methods, Atmos. Chem. Phys., 8, 6681-6698, doi:10.5194/acp8-6681-2008, 2008.

Taipale, R., Ruuskanen, T. M., and Rinne, J.: Lag time determination in DEC measurements with PTR-MS, Atmos. Meas. Tech., 3, 853-862, doi:10.5194/amt-3-853-2010, 2010.

Tani, A., Hayward, S., Hansel, A., and Hewitt, C. N.: Effect of water vapour pressure on monoterpene measurements using proton transfer reaction-mass spectrometry (ptr-ms), Int. J. Mass Spectrom., 239, 161-169, 2004.

Taraborrelli, D., Lawrence, M. G., Butler, T. M., Sander, R., and Lelieveld, J.: Mainz Isoprene Mechanism 2 (MIM2): an isoprene oxidation mechanism for regional and global atmospheric modelling, Atmos. Chem. Phys., 9, 2751-2777, doi:10.5194/acp-92751-2009, 2009.

Whalley, L. K., Furneaux, K. L., Edwards, P. E., Heard, D. E., et al.: The Chemistry of $\mathrm{OH}$ and $\mathrm{HO}_{2}$ in a tropical rainforest, Atmos. Chem. Phys. Discuss. in preparation, 2010.

Wild, O., Law, K. S., McKenna, D. S., Bandy, B. J., Penkett, S. A., and Pyle, J. A.: Photochemical trajectory modeling studies of the North Atlantic region during August 1993, J. Geophys. Res., 101, 29269-29288, 1996.

Wilkinson, M. J.: Circadian control of isoprene emissions from oil plam (Elaeis guineensis), PhD theis, Lancaster University, 2006.

Williams, J., Poschl, U., Crutzen, P. J., Hansel, A., Holzinger, R., Warneke, C., Lindinger, W., and Lelieveld, J.: An atmospheric chemistry interpretation of mass scans obtained from a proton transfer mass spectrometer flown over the tropical rainforest of Surinam, J. Atmos. Chem., 38, 133-166, 2001.

Zhang, Y., Huang, J. P., Henze, D. K., and Seinfeld, J. H.: Role of isoprene in secondary organic aerosol formation on a regional scale, J. Geophys. Res.-Atmos., 112, D20207, doi:10.1029/2007JD008675, 2007.

Zimmerman, P. R., Greenberg, J. P., and Westberg, C. E.: Measurements of atmospheric hydrocarbons and biogenic emission fluxes in the Amazon boundary-layer, J. Geophys. Res.-Atmos., 93, 1407-1416, 1988. 